МИНИСТЕРСТВО ОБРАЗОВАНИЯ И НАУКИ РОССИЙСКОЙ ФЕДЕРАЦИИ

АДЫГЕЙСКИЙ ГОСУДАРСТВЕННЫЙ УНИВЕРСИТЕТ

ЭКОНОМИЧЕСКИЙ ФАКУЛЬТЕТ

КАФЕДРА ЭКОНОМИКИ И УПРАВЛЕНИЯ

Б. И. Хутыз
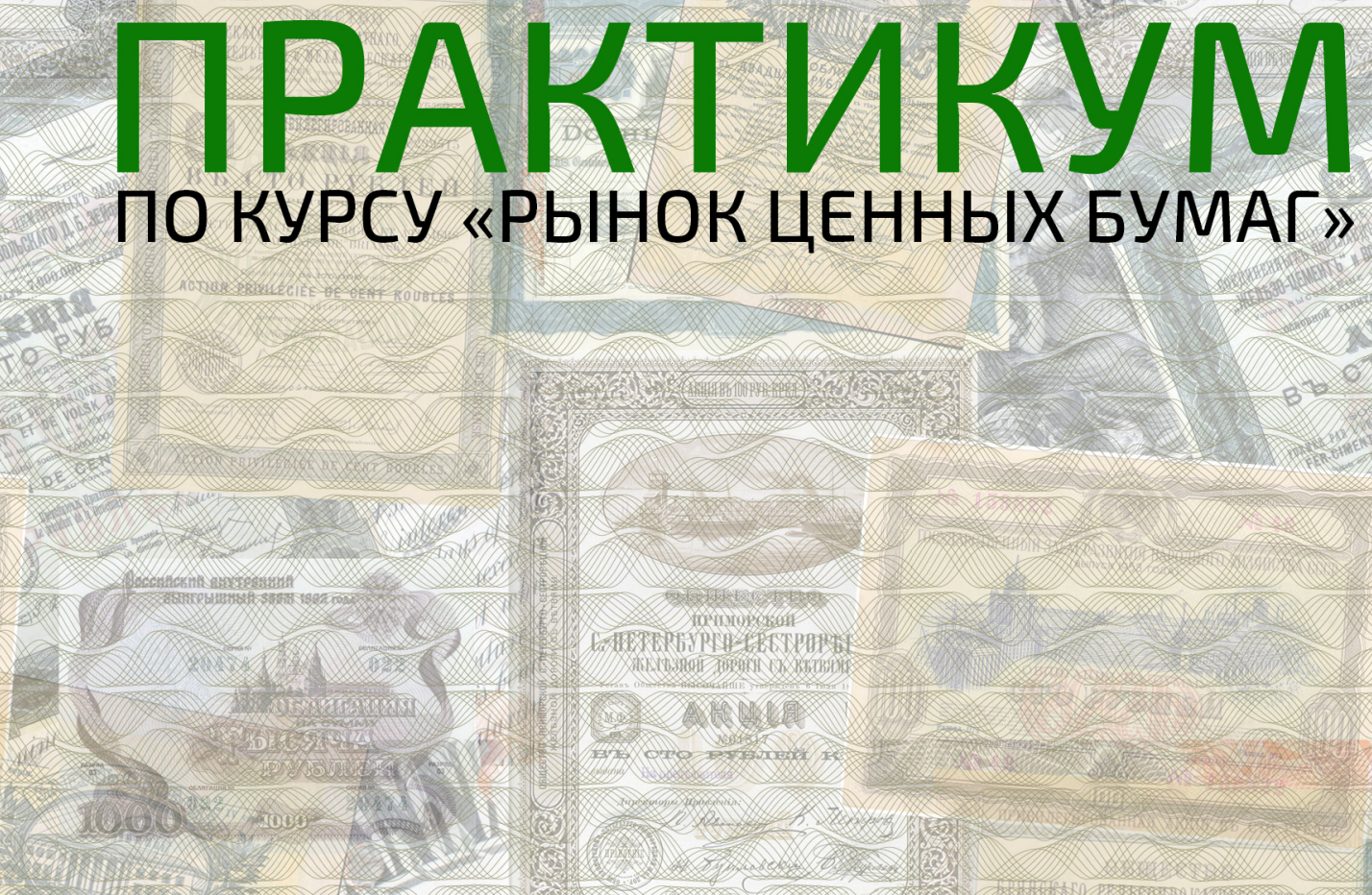
УДК 336.763(075.8)

ББК 65.264я 73

$\mathrm{X} 98$

Публикуется по решению редакционного издательской комиссии при научно-методическом совете Адыгейского государственного университета

\section{Хутыз Б.И.}

Практикум по курсу «Рынок ценных бумаг». [Электронный ресурс]: учебное электронное издание / Б.И. Хутыз Электрон. дан. (7 Мб). - Майкоп: МирИТ, 2014. - 1 электрон. опт. диск (CD-R).

№ государственной регистрации 0321402005 от 21.07.2014 г.

\section{Рецензенты:}

$\begin{array}{llll}\text { Шевченко И.В. } & \text { профессор ФГБОУ ВПО «Кубанский } \\ & \text { государственный университет», доктор } \\ & \text { экономических наук } & \\ \text { Тлехурай-Берзегова Л.Т. } & - \text { профессор ФГБОУ ВПО «Адыгейский } \\ & \text { государственный университет», доктор } \\ & \text { экономических наук }\end{array}$

\section{Цифровое представление печатного издания:}

\section{Х 98 Хутыз Б.И.}

Практикум по курсу «Рынок ценных бумаг». Учебно-методическое пособие / Б.И. Хутыз. - Майкоп: изд-во "Магарин О.Г.", 2013. - 112 с.

ISBN 978-5-91692-152-6.

Практикум разработан для углубления теоретических знаний и приобретения практических навыков, связанных с деятельностью на рынке ценных бумаг. Включает задачи, кроссворды, тестовые задания, примеры решения задач, а также содержит задания по темам, входящим в программу базового курса Федеральной службы по финансовым рынкам (ФСФР). Представленный материал способствует пониманию природы и видов ценных бумаг, организации рынка ценных бумаг, биржевых операций.

Для студентов, аспирантов, преподавателей и всех, кто интересуется механизмами функционирования рынка ценных бумаг. 


\section{СОДЕРЖАНИЕ}

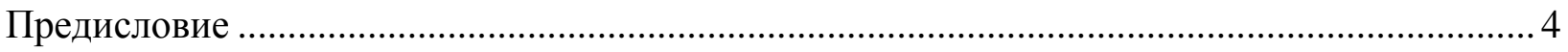

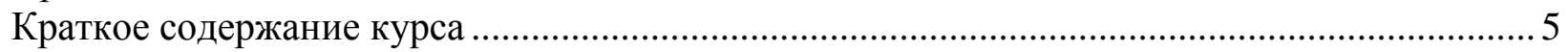

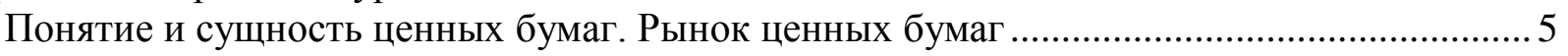

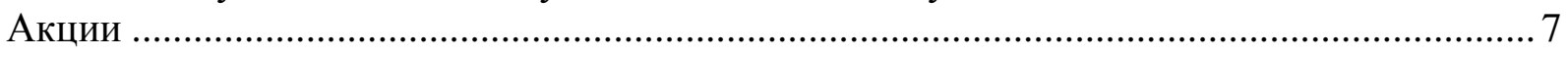

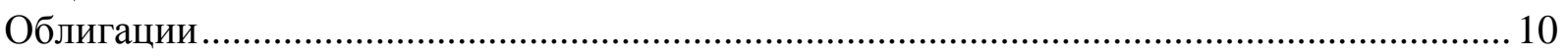

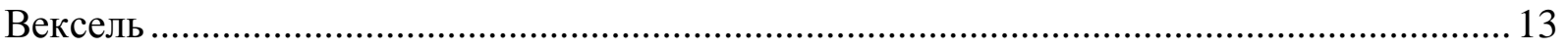

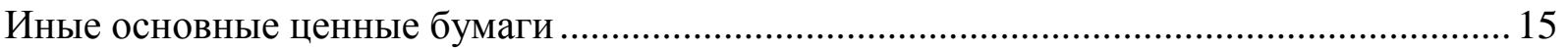

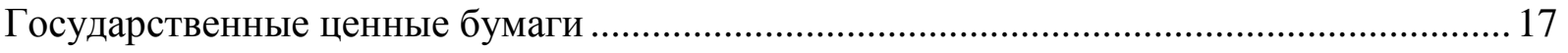

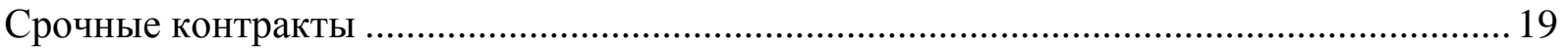

Участники рынка ценных бумаг. Регулирование рынка ценных бумаг.......................... 22

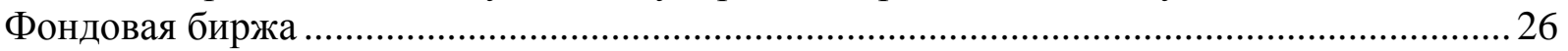

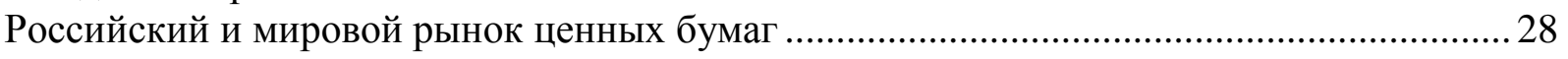

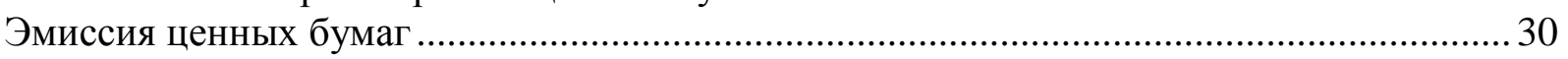

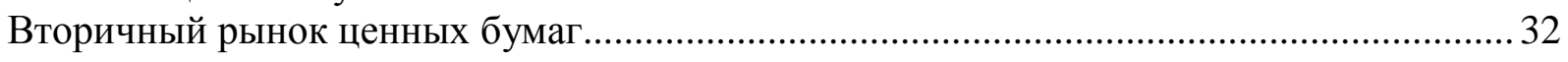

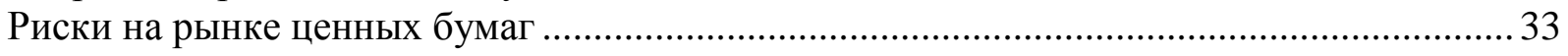

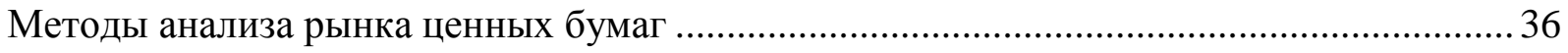

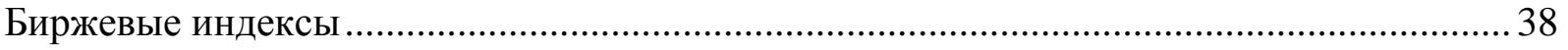

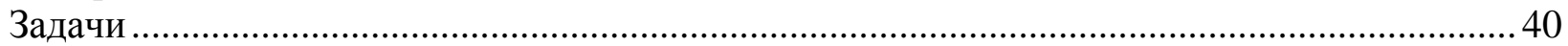

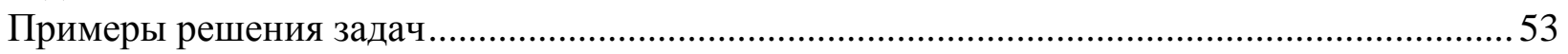

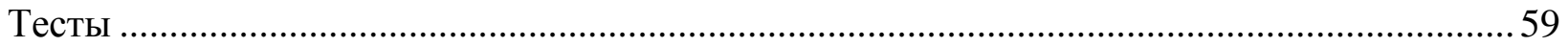

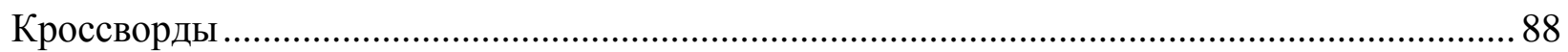

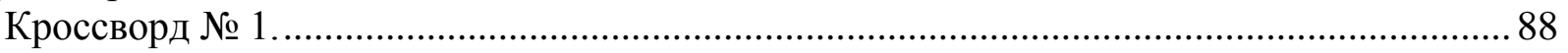

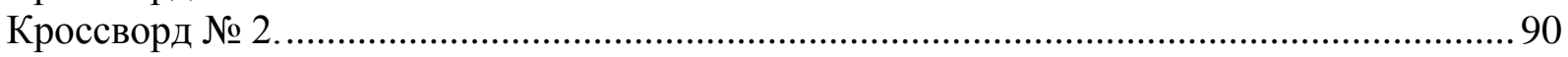

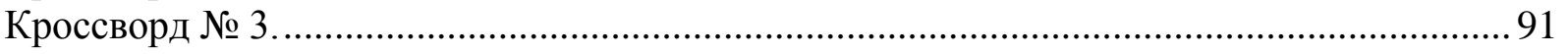

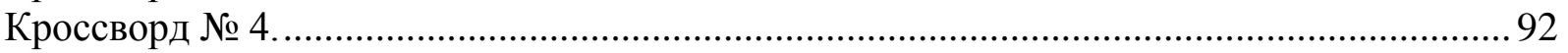

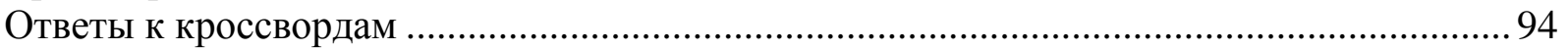

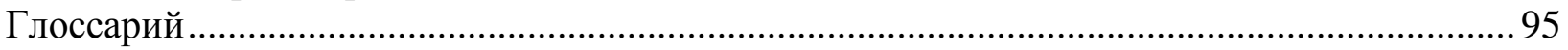

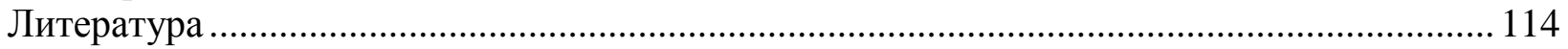




\section{Предисловие}

В последнее время интерес к ценным бумагам и биржевому рынку значительно вырос. Это обусловлено значением фондового рынка в концентрации и перераспределении финансовых источников экономического роста.

Цель настоящего практикума - оказать помощь желающим в изучении такого важного финансового инструмента рынка как ценные бумаги. Основной задачей предлагаемого издания является кратко и доходчиво объяснить читателю основные понятия, связанные с ценными бумагами, сформировать определенные навыки в области ценных бумаг и рынка ценных бумаг, которые в дальнейшем могли бы использоваться в практической деятельности.

В пособии рассматривается экономическая природа ценных бумаг, порядок их обращения, функции и роль. Особое внимание уделяется таким видам фондовых ценностей как акции, облигации, векселя, государственные и муниципальные облигации, срочные контракты. Представлены методические подходы к расчетам доходности операций с различными видами ценных бумаг. Для лучшего усвоения материала практикум содержит большое количество тестовых заданий, задач; кроссворды, призванные сделать процесс обучения более увлекательным. Рассмотрены примеры решения наиболее типовых задач. Прилагаемый глоссарий раскрывает значение специфической терминологии, используемой в практической деятельности.

Практикум разработан в соответствии с требованиями ФГОС ВПО третьего поколения по направлению подготовки «Менеджмент», квалификации «бакалавр». Пособие может быть также рекомендовано всем, кого интересуют механизмы работы рынка ценных бумаг, в том числе для самостоятельного изучения. 


\section{Краткое содержание курса}

\section{Понятие и сущность ценных бумаг. Рынок ценных бумаг}

Согласно ст.142 Гражданского кодекса РФ ценная бумага - это документ установленной формы и реквизитов, удостоверяющий имущественные права, осуществление или передача которых возможны только при его предъявлении.

Ст. 143 ГК устанавливает, что документ может быть отнесен к классу ценных бумаг только по закону или в установленном законом порядке.

Ценная бумага (далее по тексту ЦБ) - это форма существования капитала, отличная от его товарной, производительной и денежной форм, которая может передаваться вместо него самого, обращаться на рынке как товар и приносить доход.

Качество ЦБ проявляется в следующих характеристиках:

- ликвидность ЦБ - сочетание права на ее передачу от одного владельца к другому с возможностью осуществления этого права;

- доходность ценной бумаги - это доход, который она приносит в абсолютном или относительном выражении за определенный промежуток времени, обычно в расчете на год;

- риск ЦБ - т.е. неопределенность, неизвестность, связанная с осуществлением прав (и, прежде всего, прав на доход и на обращение), которыми она наделена. Понятие риск существует в трех формах: риск отдельной ЦБ, риск портфеля ЦБ, и рыночный риск, т.е. риск, свойственный рынку ЦБ в целом. Риск не является постоянным, а непрерывно изменяется.

Все ЦБ обладают определенными реквизитами и отсутствие какоголибо из обязательных реквизитов, лишает ее статуса ЦБ. К техническим реквизитам относятся: порядковые номера, адреса, подписи, печати, 
наименование организаций, обслуживающих реализацию прав владельцев ЦБ и т.д.

К экономическим реквизитам относятся: форма существования, срок существования, принадлежность, обязанное лицо, номинал, предоставляемые права.

В соответствии со ст.ст. 143, 912 ГК к ЦБ относятся: государственная облигация, облигация, вексель, чек, депозитный сертификат, сберегательный сертификат, банковская сберегательная книжка на предъявителя; коносамент, акция, приватизационные ЦБ, двойное складское свидетельство, складское свидетельство как часть двойного свидетельства, залоговое свидетельство (варрант) как часть двойного свидетельства, простое складское свидетельство. В соответствии с законом «Об ипотеке» введена закладная.

ЦБ классифицируют по эмитентам, времени обращения, способу выплаты дохода, экономической природе, уровню риска, территориям и др.

В настоящее время в странах с развитой рыночной экономикой существуют, действуют и развиваются три рынка ЦБ: внебиржевой (первичный), вторичный (фондовая биржа), уличный рынок, или рынок «через прилавок».

Внебиржевой первичный рынок охватывает лишь новые выпуски ЦБ и, главным образом, размещение облигаций торгово-промышленных корпораций, на нем также осуществляется продажа акций. Степень развитости первичного рынка зависит от развития экономики в целом, кредитно-финансовой системы, сложившейся традиции рынка ЦБ и накопления денежного капитала. Наиболее развиты первичные рынки в США, Японии, Канаде и западной Европе.

На вторичном биржевом рынке (фондовой бирже) обращаются ЦБ, прошедшие через первичный рынок. В основном оборот составляют акции и в меньшей степени облигации. Биржа больше связана с перераспределением 
собственности и капиталов, хотя и выполняет функцию по мобилизации денежного капитала в экономику.

Внебиржевой рынок ЦБ образовался в связи с ограничениями по приему акций к котировке на фондовой бирже, монополизацией биржевой торговли. Носит как организованный, так и неорганизованный (уличный) характер.

\section{Акции}

Акция - эмиссионная ЦБ, закрепляющая права ее владельца (акционера) на получение части прибыли акционерного общества в виде дивидендов, на участие в управлении акционерным обществом и на часть имущества, остающегося после его ликвидации.

Свойства акций:

- титул собственности;

- не имеет срока существования;

- ограниченная ответственность;

- неделимость;

- могут расщепляться и консолидироваться. Уставный капитал при этом не меняется.

Акция должна иметь следующие реквизиты: фирменное наименование акционерного общества и его местонахождение, наименование ЦБ «акция», ее порядковый номер, дата выпуска, вид акции (обыкновенная или привилегированная), номинальная стоимость, если именная - имя держателя, размер уставного фонда на день выпуска акций, количество выпускаемых акций, подпись председателя АО, печать эмитента.

В зависимости от порядка владения акции могут быть именными и на предъявителя. Акции также делятся на размещенные и объявленные. Размещенными считаются акции, уже приобретенные акционерами. 
Объявленными являются акции, которые $\mathrm{AO}$ может выпустить дополнительно к ранее размещенным акциям.

В зависимости от объема прав акции делятся на обыкновенные и привилегированные (преференциальные). Доля привилегированных акций в уставном капитале не должна превышать 25\%.

Дивиденд - это доход, который может получить акционер за счет чистой прибыли текущего года акционерного общества, которая распределяется между держателями акций в виде определенной доли их номинальной стоимости, т.е. через дивиденд реализуется право акционера на участие в прибыли, получаемой акционерным обществом.

Дивиденды могут выплачиваться как наличными, так и в виде дополнительных акций. Решение о выплате годовых дивидендов (размере и форме выплаты) по каждой категории акций принимает общее собрание акционеров по рекомендации совета директоров (наблюдательного совета) общества, а решение о выплате промежуточных дивидендов принимается советом директоров (наблюдательным советом) самостоятельно.

Размер годового дивиденда не может быть больше рекомендованного советом директоров (наблюдательным советом), но не может быть и меньше промежуточных дивидендов.

Все акции обладают потребительной, номинальной, эмиссионной и курсовой (рыночной) стоимостями, обратимостью и ликвидностью.

Номинальная стоимость - формируется эмитентом при выпуске акций. Она указана на лицевой стороне акции. Уставный капитал общества составляется из номинальной стоимости акций общества, приобретенных акционерами, или равен сумме номиналов акций в обращении.

Эмиссионная стоимость - стоимость размещения акций на первичном рынке. По закону эмиссионная цена акции превышает номинальную стоимость или равна ей. Превышение эмиссионной стоимости над 
номинальной стоимостью называется эмиссионным выручкой, или эмиссионным доходом. Он не может быть использован на цели потребления и должен быть присоединен к собственному капиталу АО.

Рыночная стоимость - цена акции на вторичном рынке ЦБ. Необходимость в рыночной оценке акций проявляется при поглощении и слиянии общества; покупке голосующего пакета акций; выдаче кредита под обеспечение акций; преобразовании ОАО в ЗАО; определении целесообразности выкупа ранее реализованных собственных акций; разделении и выделении общества; ликвидации общества.

Рыночной стоимостью имущества, включая стоимость акций или иных ценных бумаг общества, является цена, по которой продавец, имеющий полную информацию о стоимости имущества и не обязанный его продавать, согласен был бы продать его, а покупатель, имеющий полную информацию о стоимости имущества и не обязанный его приобрести, согласен был бы приобрести.

Рыночная цена обычно устанавливается на торгах на фондовой бирже и отражает действительную цену акции при условии большого объема сделок.

Потребительная стоимость акции - заключается в ее способности приносить доход в виде дивиденда и в результате роста курсовой стоимости. Бухгалтерская (балансовая) стоимость акций - зависит от количества выпущенных акций и реального накопления капитала.

Обратимость акции - предполагает наличие у владельца акции возможности в любой момент реализовать ее, т.е. превратить в деньги. Такая возможность во многом определяется ликвидностью РЦБ, на котором акции выступают объектом купли-продажи. Чем лучше организован рынок, чем надежнее акции, тем выше ликвидность, т.е. скорость превращения акций в деньги без потерь. 


\section{Облигации}

Облигация - это эмиссионная ЦБ, закрепляющая право ее держателя на получение от эмитента облигации в предусмотренный ею срок ее номинальной стоимости и зафиксированного в ней процента от этой стоимости или иного имущественного эквивалента.

Порядок выпуска облигаций регламентируется Законом «Об акционерных обществах». В соответствии с ним при выпуске облигаций должны быть соблюдены следующие условия:

- номинальная стоимость всех выпущенных обществом облигаций не должна превышать размер уставного капитала общества либо величину обеспечения, предоставленного обществу третьими лицами для целей выпуска;

- выпуск облигаций допускается после полной оплаты уставного капитала;

- выпуск облигаций без обеспечения допускается на третьем году существования общества и при условии надлежащего утверждения к этому времени двух годовых балансов общества;

- общество не вправе размещать облигации, конвертируемые в акции общества, если количество объявленных акций общества меньше количества акций, право на приобретение которых предоставляют облигации.

В зависимости от эмитента различают облигации: государственные, корпоративные, иностранные.

В зависимости от сроков, на которые выпускается заем, все облигации условно делят на 2 группы:

1) облигации с некоторой оговоренной датой погашения; 
2) облигации без фиксированного срока погашения (включают: бессрочные или непогашаемые; отзывные облигации; облигации с правом погашения; продлеваемые облигации; отсроченные облигации).

В зависимости от порядка права владения облигации могут быть именными и на предъявителя; по целям облигационного займа - обычные; целевые.

Погашение номинала облигации может производиться разовым платежом или бывают с распределенным по времени погашением, когда за определенный отрезок времени погашается некоторая доля номинала.

В зависимости от того, какие выплаты производятся эмитентом, различают:

- облигации, по которым производится только выплата процентов, а капитал не возвращается: эмитент указывает на возможность их выкупа, не указывая конкретный срок;

- облигации, по которым лишь возвращается капитал, а процент не выплачивается (с нулевым купоном);

- облигации, по которым выплачивается совокупный купонный доход только в момент погашения;

- облигации, по которым возвращается капитал по номинальной стоимости, а выплата процентов не гарантируется и находится в прямой зависимости от прибыли предприятия;

- облигации, дающие право еe владельцам на получение периодически выплачиваемого фиксированного дохода, а номинальной стоимости в будущем - при погашении.

В зависимости от способа выплаты купонного дохода:

- облигации с фиксированной купонной ставкой;

- облигации с плавающей купонной ставкой, когда купонная ставка зависит от уровня ссудного процента; 
- облигации с равномерно возрастающей купонной ставкой по годам займа;

- облигации с минимальным или нулевым купоном.

По характеру обращения различают неконвертируемые и конвертируемые облигации; по обеспеченности залогом - обеспеченные и не обеспеченные залогом.

Облигации имеют нарицательную цену (номинал) и рыночную цену. Номинальная цена - напечатана на самой облигации и обозначают сумму, которая берется взаймы и подлежит возврату по истечении срока займа. С момента эмиссии облигации покупаются-продаются по эмиссионной цене, которая может быть выше, ниже или равна номиналу. В дальнейшем, исходя из ситуации, сложившейся на рынке, складывается рыночная цена.

Для сопоставления рыночных цен облигаций используется курс облигаций.

Общий доход по облигации складывается из следующих элементов:

- периодически выплачиваемых процентов (купонного дохода);

- изменения стоимости облигации за соответствующий период;

- дохода от реинвестирования полученных процентов.

Облигация может приносить доход в виде прироста капитала в результате разницы между ценой покупки и ценой продажи. Данный вид дохода приносят, прежде всего, облигации, купленные ниже номинала, т.е. с дисконтом.

Различают текущую и полную (конечную) доходность облигаций.

Текущая доходность характеризует годовые (текущие) поступления по облигации относительно произведенных затрат на ее покупку.

Конечная (полная) доходность облигации характеризует полный доход по облигации, приходящийся на единицу затрат на покупку этой облигации в расчете на год. 


\section{Вексель}

Вексель - это инструмент денежного рынка, не эмиссионная долговая ценная бумага.

В зависимости от эмитента различают векселя казначейские, муниципальные, частные. В зависимости от срока платежа могут быть определенно срочные и неопределенно срочные (дата платежа не определена и зависит от векселедержателя).

В зависимости от возможности передачи третьему лицу индоссируемые и не индоссируемые.

Переводной вексель (тратта) - письменный документ, содержащий безусловный приказ векселедателя плательщику уплатить определенную сумму денег в установленный срок и в конкретном месте векселедержателю или его приказу. Плательщик и векселедатель - разные лица.

Простой вексель (соло) - письменный документ, содержащий простое и ничем не обусловленное обязательство векселедателя (должника) уплатить определенную сумму денег в установленный срок и в конкретном месте векселедержателю или его приказу. В простом векселе векселедатель является прямым должником.

Соло-векселя используются банками в следующих направлениях:

- привлечение временно свободных денежных средств;

- вексельное кредитование;

- вексель как средство платежа.

Банки выпускают векселя процентные и дисконтные. Процентные продаются по номиналу, а при представлении векселя к погашению векселедержателю выплачивается номинал, а также проценты по нему. Такие векселя неопределенно срочные (оплачиваются по предъявлении или не раньше такого-то времени от составления). 
Дисконтные векселя продаются ниже номинала (со скидкой дисконтом). Такие векселя определенно срочные, т.е. оговаривается срок погашения такого векселя.

Переводной вексель содержит следующие реквизиты: вексельные метки; вексельная сумма; наименование и адрес плательщика; срок платежа; наименование получателя платежа; место платежа; указание места и даты составления; подпись векселедателя.

К обязательным реквизитам простого векселя относятся: наименование «вексель» включенное в текст на том языке, на котором документ составлен; простое и ничем не обусловленное обязательство уплатить определенную сумму; срок платежа; место платежа; наименование получателя платежа; место и дата составления векселя; подпись векселедателя.

Акцепт переводного векселя (тратты) - согласие оплатить по векселю в пользу векселедержателя, предъявившего его к оплате. Лицо, совершившее акцепт называется акцептантом.

Аваль - вексельное поручительство, суть которого в том, что какое-то лицо берет на себя ответственность за платеж по векселю одного или нескольких ответственных по векселю лиц.

Индоссамент - это передаточная надпись на оборотной стороне векселя. Индоссамент фиксирует переход права требования по векселю от одного лица к другому.

Виды индоссамента: именной; бланковый; инкассовый; залоговый. Переход права собственности на вексельную сумму фиксируют именной и бланковый индоссаменты.

Учет векселей представляет собой оплату банком векселя до наступления срока платежа. 


\section{Иные основные ценные бумаги}

Банковский сертификат - это единственный вид ЦБ, выпускать которую имеет право только коммерческий банк. Выпускается в виде депозитного и сберегательного сертификата.

Депозитный сертификат - ЦБ, удостоверяющая сумму вклада, внесенного в банк юридическим лицом, и его права на получение в этом банке или в его филиалах по истечении установленного срока суммы вклада и причитающихся по нему процентов.

Сберегательный сертификат - ЦБ, удостоверяющая сумму вклада, внесенного в банк гражданином, и его права на получение в этом банке или в его филиалах по истечении установленного срока суммы вклада и причитающихся по нему процентов.

Существуют в документарной форме. Могут быть именными и на предъявителя. Именные сертификаты передаются путем оформления цессии на оборотной стороне, которая скрепляется подписями и печатями сторонучастников сделки.

Расчеты по депозитным сертификатам осуществляются только в безналичном порядке.

Банковский сертификат, в отличие от векселя и чека, не может служить расчетным и платежным средством при купле продаже товаров и услуг.

Чек - есть особая форма переводного векселя, плательщиком по которому всегда выступает банк.

Чек - это ЦБ, содержащая ничем не обусловленное распоряжение чекодателя банку произвести платеж указанной в нем суммы чекодателю. 
Существует в документарной форме, может быть предъявительским, ордерным и именным. Именной чек не подлежит передаче, ордерный передается путем индоссамента.

Коносамент - это документ стандартной формы, принятой в международной практике, на перевозку груза, который удостоверяет его погрузку, перевозку и право на получение.

Коносамент бывает следующих форм: на предъявителя, именной (не подлежит передаче другому лицу), ордерный (передается с помощью индоссамента). Это документ, в котором никакие изменения невозможны.

Складское свидетельство - это ЦБ, удостоверяющая принятие товара на хранение по договору складского хранения.

Складское свидетельство существует в документарной форме; бывает на предъявителя (простое складское свидетельство) и именное (двойное складское свидетельство).

Двойное складское свидетельство состоит из двух частей складского свидетельства и залогового свидетельства (варранта), которые могут быть отделены друг от друга, и каждое по отдельности является ценной бумагой.

Закладная - это именная ЦБ, удостоверяющая права ее владельца в соответствии с договором об ипотеке (залоге недвижимого имущества) на получение денежного обязательства или указанного в нем имущества. Существует в документарной форме, именная ЦБ.

Закладная обращается аналогично векселю, может передаваться в залог, быть объектом купли-продажи, переходить по наследству. 


\section{Государственные ценные бумаги}

Государственные ценные бумаги (далее ГЦБ) - это долговые ЦБ, эмитентом которых выступает государство, т.е. это форма существования государственного внутреннего долга.

Каждая ГЦБ имеет собственное название, позволяющее отличать ее от других видов облигаций.

Функции ГЦБ:

1) финансирование дефицита госбюджета на неинфляционной основе, т.е. без выпуска денег;

2) финансирование целевых государственных программ в области жилищного строительства, инфраструктуры, социального обеспечения;

3) регулирование экономической активности: денежной массы в обращении, воздействие на цены и инфляцию, на расходы и направления инвестирования.

Особенности размещения ГЦБ:

- через Центробанк или Минфин;

- в бумажной (бланковой) или безбумажной формах (в виде записей на счетах в уполномоченных депозитариях);

- разнообразными методами: аукционные торги, открытая продажа всем желающим по установленным ценам, закрытое распространение среди определенного круга инвесторов и т.д.

На различных этапах развития рынка в Российской Федерации выпускались следующие виды государственных ценных бумаг:

1) государственный республиканский внутренний заем РСФСР 1991г.;

2) облигации внутреннего валютного займа 1993г.;

3) государственные краткосрочные бескупонные облигации (ГКО); 
4) облигации федерального займа (ОФ3);

5) облигации государственного сберегательного займа (ОГСЗ);

6) государственные облигации, погашаемые золотом (золотые сертификаты);

7) казначейские векселя;

8) государственные облигации, размещаемые на мировом рынке (еврооблигации, евробонды).

Региональные ЦБ - это способ привлечения финансовых ресурсов региональными органами государственной власти в случае дефицита регионального бюджета или на инвестиционные цели путем выпуска долговых ЦБ.

Цели выпуска региональных ЦБ группируются следующим образом:

- покрытие временного дефицита регионального бюджета;

- финансирование бесприбыльных проектов, требующих единовременных вложений крупных средств, которыми не располагает ежегодный бюджет (строительство, ремонт и т.д. школ, больниц, музеев, дорог, водосетей);

- финансирование прибыльных проектов, вложения в которые окупаются в течение нескольких лет за счет прибыли;

- финансирование проектов строительства, ремонта и реконструкции жилья, как правило, на основе их самоокупаемости (т.е. часть жилфонда реализуется).

По закону объем расходов по обслуживанию регионального займа не может превышать $15 \%$ объема расходов бюджета соответствующего уровня, а предельный размер заемных средств не может превышать $30 \%$ доходов бюджета субъектов федерации и 15\% доходов бюджета муниципальных образований без учета в обоих случаях поступлений из федерального бюджета и привлеченных заемных средств. 


\section{Срочные контракты}

Сделки, предполагающие поставку актива в будущем, когда их исполнение предусматривается через определенный срок по курсу, зафиксированному в момент заключения договора, называются срочными.

Срочные сделки подразделяются на условные сделки, предоставляющие одному из контрагентов право исполнить или не исполнить заключенный контракт, и твердые сделки, обязательные для исполнения.

Форвардные контракты представляют собой внебиржевые срочные сделки о купле-продаже в будущем товара с исполнением в заранее оговоренный срок. Это срочный договор с обязательным его исполнением каждой из сторон, т.е. твердая сделка.

Права и обязательства любой из сторон контракта прекращаются либо в результате его исполнения, либо в результате заключения обратной сделки.

Достоинство форвардного контракта - это возможность его приспособления к индивидуальным запросам сторон контракта по любым параметрам заключаемой сделки (по цене, срокам, размерам, форме расчетов). Форвардный вид контракта, не являясь стандартным, сложен при передаче взятых обязательств третьему лицу.

Фьючерсный контракт - это стандартный биржевой договор куплипродажи (поставки) биржевого актива через определенный срок в будущем по цене, установленной сторонами сделки в момент ее заключения.

Фьючерсные контракты могут заканчиваться поставкой участниками сделки фондовых ценностей, или выплатой одним из участников сделки другому разницы между контрактной ценой и биржевой на дату исполнения 
платежа по контракту. Фьючерсный контракт полностью стандартизирован, т.е. все его параметры, кроме цены, известны заранее и не зависят от желания сторон.

Каждый фьючерсный контракт имеет две стороны: покупатель, или сторона, имеющая длинную позицию, и продавец, или сторона, имеющая короткую позицию.

Разница в стоимости контракта в момент его заключения и в момент ликвидации составляет либо прибыль участника, которая поступит на его счет, либо убыток, который будет списан с его счета. Разница в стоимости контракта по длинной и короткой позициям определяется как разница между ценой исполнения сделки и текущей котировкой на срочном рынке, умноженная на количество товара.

Опцион - предоставляет право выбора купить или продать определенное количество товара по зафиксированной цене в оговоренный срок или раньше. В биржевом опционе стандартизированы количество базового актива (им может быть валюта, ЦБ, товары, фьючерсные контракты и т.д.), его качество; указаны период обращения, срок прекращения действия, условия поставки-приемки и т.д.

В результате опционных сделок не происходит непосредственно процесс купли-продажи, например, ЦБ; приобретаются не ЦБ, а право на их приобретение.

Сделка с премией - это сделка, при которой сторона - плательщик премии получает право отступного, т.е. за уплату ранее установленной суммы отказывается от выполнения контракта в случае его невыгодности или теряет определенную сумму в случае исполнения контракта.

Опцион, который дает право купить актив, называется опционом на покупку или опционом колл (call), или просто коллом. Опцион, который дает 
право продать актив, называется опционом на продажу или опционом пут (put), или просто путом.

Различают опцион покупателя и опцион продавца и два вида связанных с ними вида операций - покупка и продажа. Таким образом, при заключении опционного соглашения контрагент может занять четыре основные позиции: покупка call-опциона, покупка put-опциона, продажа callопциона, продажа put-опциона.

Варрант предоставляет его владельцу право приобрести ЦБ по заранее установленной цене в течение определенного времени. Владелец варранта — это покупатель. Лицо, осуществляющее эмиссию этих производных ЦБ и принимающее соответствующие обязательства по отношению к покупателю варранта, есть продавец варранта.

Своп - это договор обмена базовыми активами и (или) платежами на их основе в течение установленного периода, в котором цена одного из активов является твердой (фиксированной), а цена другого - переменной (плавающей), или же обе эти цены являются переменными.

Основные виды свопов:

Процентный своп - обмен займа с фиксированной банковской процентной ставкой; обмен займами с плавающей процентной ставкой, имеющими разную базу. Валютный своп - обмен валютами или валютными обязательствами в будущем по фиксированному или плавающему курсу. Товарный своп - обмен товарного актива с фиксированной ценой на тот же или иной товарный актив с плавающей ценой. Индексный своп - обмен актива с фиксированной ставкой процента на актив, доходность которого зависит от согласованного фондового индекса. 


\section{Участники рынка ценных бумаг. Регулирование рынка ценных бумаг}

Участники РЦБ - это физические лица или организации, которые продают либо покупают ЦБ, обслуживают их оборот и расчеты по ним. В зависимости от их функционального назначения существуют следующие группы участников РЦБ:

- продавцы - это эмитенты и владельцы ЦБ;

- инвесторы - те, кто вкладывает, инвестирует свой реальный капитал в ЦБ;

- фондовые посредники - это торговцы, обеспечивающие связь, между эмитентами и инвесторами на РЦБ (осуществляют брокерскую, дилерскую или деятельность по управлению ЦБ);

- организации, обслуживающие РЦБ - это организации, выполняющие все другие функции на РЦБ, кроме купли-продажи этих ЦБ (фондовые биржи, небиржевые организаторы рынка, расчетные центры, депозитарии, регистраторы, информационные агентства и др.);

- органы регулирования и контроля - высшие органы управления, министерства и ведомства, Центробанк РФ.

Эмитент - это юридическое лицо, группа юридических лиц, связанных между собой договором, или органы государственной власти и местного самоуправления, несущие от своего имени обязательства перед инвесторами по осуществлению прав, удостоверенных ЦБ.

Инвестор - это лицо, которому ЦБ принадлежат на праве собственности или ином вещном праве.

В зависимости от статуса инвесторы делятся на физических лиц, корпоративных и коллективных инвесторов (фонды, страховые компании и т.д.) и государство. 
Юридические лица, не являющиеся профессиональными участниками РЦБ, купившие ЦБ за свой счет и от своего имени, являются институциональными инвесторами.

В зависимости от цели инвестирования инвесторов подразделяют на стратегических, портфельных и спекулянтов.

В зависимости от отношения к риску инвесторы делятся на следующие группы: консервативный (робкий) инвестор; умеренноагрессивный; агрессивный инвестор; изощренный инвестор; нерациональный инвестор.

К профессиональной деятельности согласно Федеральному закону «О РЦБ» относятся: брокерская; дилерская, по управлению ЦБ, по определению взаимных обязательств (клиринг), депозитарная, по ведению реестра ЦБ, по организации торговли на РЦБ.

Брокерской деятельностью признается совершение гражданскоправовых сделок с ЦБ в качестве поверенного или комиссионера, действующего на основе договора-поручения или комиссии либо доверенности на совершение таких сделок.

В качестве брокера могут выступать физические или юридические лица. Профессиональная брокерская деятельность осуществляется на основании лицензии, которая выдается Федеральной службой по финансовым рынкам (ФСФР России) или в уполномоченных организациях, получивших у нее генеральную лицензию. Законом допускается совмещение брокерской деятельности с другими видами деятельности на РЦБ.

По договору поручения брокер выступает от имени клиента и за счет клиента. По договору комиссии брокер действует от своего имени, но в интересах клиента и за его счет.

Дилерской деятельностью признается совершение сделок куплипродажи ЦБ от своего имени и за свой счет путем публичного объявления 
цен покупки или продажи определенных ЦБ с обязательством покупки или продажи ЦБ по объявленным лицом, осуществляющим такую деятельность, ценам. Дилером может быть только коммерческое юридическое лицо.

Функции дилера:

- совершение сделок купли-продажи ЦБ за свой счет и от своего имени путем публичного объявления цен покупки или продажи определенных ЦБ по объявленным дилером ценам;

- дополнительные обязательства по обеспечению ликвидности РЦБ;

- раскрытие информации о своих операциях с ЦБ в случаях и в порядке, предусмотренных действующим законодательством.

Регистраторами на РЦБ обычно называют организации, которые по договору с эмитентом ведут реестр. Реестром называется список владельцев именных ЦБ, составленный на определенную дату.

Ведение реестра самим эмитентом возможно только в случае, если число держателей не превышает 500. Регистратор не может совмещать эту деятельность с другими видами профессиональной деятельности, т.е. ведение реестра собственников именных ЦБ рассматривается как исключительная.

Депозитарием называется организация, которая оказывает услуги по хранению сертификатов ЦБ и (или) учету прав собственности на ЦБ. Депозитарий ведет счета, на которых учитываются ЦБ, переданные ему клиентами на хранение, а также непосредственно хранит сертификаты этих ЦБ.

Счета, предназначенные для учета ЦБ, называются счетами депо.

Клиент депозитария называется депонентом. Депозитарная деятельность может совмещаться с другими видами профессиональной деятельности на РЦБ, кроме ведения реестра владельцев ЦБ. Депозитарная деятельность подлежит лицензированию. Лицензия выдается сроком до трех лет. 
Расчетно-клиринговая организация (РКО) - это профессиональный участник РЦБ, специализированная организация, которая осуществляет расчетное обслуживание участников организованного РЦБ и выявляет их позиции по результатам заключенных сделок.

РКО существует в форме закрытого акционерного общества или некоммерческого партнерства и должна иметь лицензию ФСФР, которая выдается на срок до трех лет.

Расчетно-клиринговые организации не имеют права проводить кредитные и большинство других активных операций (вкладывать деньги в ЦБ и т.п.) в отличие от коммерческих банков.

Биржа, согласно действующему законодательству, относится к участникам РЦБ, непосредственно способствующим заключению гражданско-правовых сделок с ЦБ. Биржа не может совмещать деятельность организации торговли ЦБ с другими видами профессиональной деятельности на РЦБ, кроме депозитарной и клиринговой.

Фондовая биржа относится к числу закрытых бирж, т.е. торговать на ней ЦБ могут только ее члены. В Росси все члены биржи равны. Не может быть временного членства, сдачи места на бирже в аренду или в залог тем лицам, которые не являются членами биржи или фондового отдела.

Регулирование РЦБ - это упорядочение деятельности на нем всех его участников и операций между ними

Регулирование может быть внешним и внутренним.

Процесс регулирования РЦБ включает:

- создание нормативно-правовой базы функционирования рынка;

- отбор профессиональных участников РЦБ;

- контроль соблюдения всеми участниками рынка норм и правил функционирования рынка; 
- систему санкций за отклонение от норм и правил, установленных на рынке.

Государственное управление РЦБ имеет следующие формы: прямое (административное) управление и косвенное (экономическое) управление.

\section{Фондовая биржа}

Фондовая биржа представляет собой финансовое посредническое учреждение с регламентированным режимом работы, где совершаются торговые сделки между продавцами и покупателями фондовых ценностей с участием биржевых посредников по официально закрепленным правилам.

Круг биржевых товаров довольно ограничен:

- товары, которые могут быть подобраны по определенным признакам (пшеница, металлы, нефть);

- валюта;

- ЦБ.

Фондовая биржа не имеет права преследовать цель получения прибыли, заниматься деятельностью в качестве инвестиционного института.

C учетом правового статуса в мировой практике существуют три типа фондовых бирж, а именно: 1) публично-правовые; 2) частные; 3) смешанные.

Публично-правовые фондовые биржи находятся под постоянным государственным контролем. Фондовые биржи как частные компании создаются в форме акционерных обществ. Такие биржи самостоятельны в организации биржевой торговли. Если фондовые биржи создаются как акционерные общества, но при этом не менее 50\% их капитала принадлежит государству, они относятся к типу смешанных организаций. Во главе таких бирж стоят выборные биржевые органы. 
В России, в соответствии с действующим законодательством, фондовые биржи создавались как закрытые акционерные общества и должны иметь не менее трех членов. Членами биржи могут быть только ее акционеры - юридические лица, а также государственные исполнительные органы, в основные задачи которых входит осуществление операций с ЦБ. Операции на фондовой бирже могут выполняться только ее членами.

ЦБ, поступающие на биржу, проверяются специальной комиссией по листингу. Задача листинга - проверка финансового положения и менеджмента компании-эмитента, которая проводится на принципах аудита.

Задача котировальной комиссии - определение курса ЦБ при ее первой реализации. Котировальная комиссия выясняет также, обладает ли предлагаемая к котировке ЦБ необходимой ликвидностью, т.е. будет ли она пользоваться спросом.

Котировка ЦБ - это механизм выявления цены, ее фиксация в течение каждого дня работы биржи и публикация в биржевых бюллетенях.

Существуют три формы временного прекращения котировки на бирже: отсрочка начала торговли; перерыв в торговле; приостановка торговли на одну сессию и более.

Делистинг - исключение из биржевого списка - может последовать, если: эмитент объявлен банкротом или его финансовое состояние признано неудовлетворительным; публичное размещение ЦБ достигает неприемлемо малых масштабов или имеется иное их несоответствие минимальным требованиям листинга; компании-эмитенты в письменном виде подают заявление об исключении их ЦБ из числа котирующихся; ЦБ эмитента отозваны для обмена на новые или погашения при их дроблении, а также при слиянии с другой фирмой и т.д.; нарушается соглашение о листинге; компанией-эмитентом не представлены ежегодный отчет и другая информация в указанные сроки. 
В зависимости от выполняемых ими функций все участники рынка ЦБ заключают реальные, спекулятивные и арбитражные сделки.

Фондовая биржа не только торговый, но также исследовательский и информационный центр РЦБ.

\section{Российский и мировой рынок ценных бумаг}

В общем виде РЦБ - это совокупность экономических отношений его участников по поводу выпуска и обращения ЦБ. Объем РЦБ намного больше рынка материальных благ и потенциально не имеет предела. ЦБ существует только в процессе обращения.

Различают следующие РЦБ:

- международные и национальные РЦБ;

- национальные и региональные (территориальные) РЦБ;

- рынки конкретных видов ЦБ (акций, облигаций и т.п.);

- рынки государственных и корпоративных (негосударственных) ЦБ;

- рынки ЦБ и производных инструментов и т.д.

Вместе с валютным и денежным рынками РЦБ входит в понятие финансового рынка.

РЦБ служит дополнительным источником финансирования экономики. Субъектами рынка являются частные предприятия, государство и индивидуальные лица, деятельность которых формирует курс ЦБ и его колебание в зависимости от рыночной конъюнктуры.

РЦБ имеет ряд функций, которые условно делятся на 2 группы: общерыночные функции, присущие каждому рынку, и специфические функции, которые отличают его от других.

К общерыночным функциям относятся:

- коммерческая функция;

- ценообразующая функция; 
- информационная функция;

- регулирующая функция.

К специфическим функциям относят:

- перераспределительную;

- функцию страхования ценовых и финансовых рисков или их перераспределения.

В РЦБ выделяют рынки: первичный и вторичный; организованный и неорганизованный; биржевой и внебиржевой; кассовый и срочный.

К основным проблемам российского рынка акций относятся:

- формирование полной законодательной и другой нормативной базы функционирования фондового рынка, обеспечивающей защиту интересов инвесторов;

- развитие инфраструктуры фондового рынка;

- повышение информационной открытости рынка;

- дальнейшая интеграция с фондовыми рынками развитых стран мира;

- вовлечение в оборот все большего числа акций (по объему и по количеству эмитентов).

Основными тенденциями развития современного РЦБ в странах с развитыми рыночными отношениями на нынешнем этапе являются:

- концентрация и централизация капиталов;

- интернационализация и глобализация рынка;

- повышение уровня организованности и усиление государственного контроля;

- компьютеризация РЦБ;

- секьюритизация;

- взаимопроникновение в другие рынки капиталов.

К новейшим тенденциям на РЦБ: 
- индивидуализацию инструментов рынка, т.е. выпуск таких ЦБ (производных инструментов), которые отвечают индивидуальным интересам отдельных эмитентов и инвесторов с точки зрения сочетания их доходности, риска, налогообложения;

- стирание различий между инструментами рынка, осуществляемое путем комбинации различных свойств уже существующих инструментов рынка на каком-либо новом инструменте («гибридном»).

\section{Эмиссия ценных бумаг}

Эмиссия ЦБ - это установленная законом последовательность действий эмитента по размещению эмиссионных ЦБ.

Обращение ценных бумаг - это заключение гражданско-правовых сделок, влекущих за собой переход прав собственности на ЦБ.

Эмиссионные ЦБ могут выпускаться в одной из следующих форм:

- именные ЦБ документарной формы выпуска (именные документарные ЦБ);

- именные ЦБ бездокументарной формы выпуска (именные бездокументарные ЦБ);

- ЦБ на предъявителя документарной формы выпуска (документарные ЦБ на предъявителя).

Одна эмиссионная ЦБ может быть удостоверена только одним сертификатом. Один сертификат может удостоверять право на одну, несколько или все эмиссионные ЦБ с одним государственным регистрационным номером.

Эмиссионные ЦБ на предъявителя могут выпускаться только в документарной форме, а именные эмиссионные ЦБ - как в документарной, так и в бездокументарной формах.

Размещение ЦБ на первичном рынке осуществляется в двух формах: 
1) путем прямого обращения к инвесторам;

2) через посредников.

Процедура эмиссии ЦБ включает следующие этапы:

- принятие эмитентом решения о выпуске ЦБ;

- регистрацию выпуска ЦБ;

- изготовление сертификатов ЦБ (для документарной формы выпуска);

- размещение ЦБ;

- регистрацию отчета об итогах выпуска ЦБ.

Для регистрации эмиссионных ЦБ эмитент обязан представить следующие документы:

- заявление на регистрацию;

- решение о выпуске ЦБ;

- проспект эмиссии (если регистрация выпуска ЦБ сопровождается регистрацией проспекта эмиссии);

- копии учредительных документов (при эмиссии акций для создания акционерного общества);

- документы, подтверждающие разрешение уполномоченного органа исполнительной власти на выпуск ЦБ (в случаях, когда необходимость такого разрешения установлена законодательством Российской Федерации).

Отчет об итогах выпуска ЦБ должен содержать следующую информацию:

- даты начала и окончания размещения;

- фактическую цену размещения (по видам ЦБ в рамках данного выпуска);

- количество размещенных ЦБ;

- общий объем поступлений за размещенные ЦБ. 
Недобросовестной эмиссией признаются действия, выражающиеся в нарушении процедуры эмиссии и являющиеся основанием для отказа в регистрации выпуска ЦБ, признания его несостоявшимся или приостановления эмиссии ЦБ.

\section{Вторичный рынок ценных бумаг}

Под обращением ЦБ понимается переход права собственности от одного их держателя (владельца) к другому при заключении ими гражданскоправовых сделок.

На РЦБ их обращение регламентируется как государством, так и самими участниками рынка через устанавливаемые ими правила торговли, стандарты, и нормы поведения.

К торгам могут быть допущены любые виды ЦБ отечественных и зарубежных эмитентов, которые будут продаваться и покупаться в той или иной торговой системе. В случае прохождения процедуры листинга ЦБ включается в котировальный бюллетень - Реестр ЦБ, допущенных к торгам.

В структуре брокерских фирм выделяют: фронт-офис - торговые подразделения брокерской компании, сотрудники которого заключают сделки с ЦБ по поручению клиентов; бэк-офис - подразделение брокерской компании, обеспечивающее исполнение сделок после их заключения и осуществляющее внутренний учет и контроль операций с ЦБ.

Основными функциями бэк-офиса являются контроль исполнения заказов клиентов; улаживание сделок; контроль соблюдения нормативов финансового состояния счетов и использования денежных средств и ЦБ клиентов; учет движения ЦБ и денежных средств; хранение ЦБ и денежных 
средств клиента; представление информации руководству фирмы и брокерам; поддержание связи между владельцами и эмитентами ЦБ.

В состав бэк-офиса брокерской фирмы входят: отдел клиентской документации, отдел заказов, отдел покупок и продаж, кредитный отдел, отдел учета движения ЦБ, отдел дивидендов, отдел по работе с реальными владельцами.

Брокеры совершают гражданско-правовые сделки с ЦБ в качестве поверенных или комиссионеров, действующих на основании договоров поручения или комиссии, а также доверенностей на совершение таких сделок.

В сферу деятельности брокерской фирмы входят оказание услуг по консалтингу, размещение ЦБ на первичном и вторичном рынках, создание и управление инвестиционными фондами и т.п. Кроме того, брокеры обычно оказывают ряд особых услуг на финансовом рынке: посредничество при получении банковского кредита, помощь в страховании сделок, в том числе биржевых, с ЦБ.

\section{Риски на рынке ценных бумаг}

Доход, получаемый инвестором от вложений в ЦБ, неизменно сопряжен с риском, представляющим собой возможность возникновения обстоятельств, при которых инвестор может понести потери.

Выделяют два типа рисков: систематический и несистематический.

Систематический риск определяется глобальными обстоятельствами, не зависящими от инвестора и эмитента. К таким обстоятельствам можно отнести политические события на уровне страны и на международном уровне, изменения законодательства, экономические реформы и т.д. Несистематический риск определяется факторами, связанными с 
деятельностью предприятия-эмитента и изменениями рыночной конъюнктуры. Несистематический риск можно уменьшить путем диверсификации портфеля; систематический же риск путем диверсификации уменьшить нельзя.

Для безрискового портфеля отсутствует только несистематический риск, систематический риск остается.

В качестве меры риска, считая эффективность некоторой ЦБ случайной величиной $\mathrm{R}$, принимается ее вариация (дисперсия).

С увеличением количества видов ЦБ в портфеле уменьшается риск инвестиций. Процедура включения в портфель различных видов ЦБ, имеющих низкий коэффициент корреляции, называется диверсификацией.

При диверсификации риск портфеля снижается только до определенного уровня, ниже которого путем диверсификации риск уменьшить нельзя. Таким образом, риск представляет собой сумму диверсифицируемого и недиверсифицируемого рисков. Диверсифицируемая часть риска представляет собой несистематический риск, а недиверсифицируемая - систематический.

В качестве допустимого риска принимают угрозу потери части прибыли от предпринимательской деятельности на фондовом рынке. Критический (катастрофический) риск сопряжен с потерей части или всей капитальной стоимости ЦБ.

По уровню оценки риски подразделяются на:

- страновые;

- отраслевые;

- риски, связанные с деятельностью отдельного оператора.

Страновые риски - это риски вложения денежных средств в ЦБ стран с неустойчивым фондовым рынком. Уровень странового риска определяет инвестиционный климат. Оцениваются экономические (инфляционные), 
фискально-монетарные (изменение денежно-кредитной, налоговой политики), социально-политические риски (например, риск военных конфликтов).

Отраслевые риски - связаны с особенностями отдельных отраслей, проявляются в изменениях инвестиционного качества и курсовой стоимости ЦБ и соответствующих потерях для инвестора в зависимости от принадлежности отрасли к тому или иному типу и правильности оценки инвесторами данных факторов.

Риски финансового оператора на рынке ЦБ делят на финансовые и коммерческие.

Финансовые риски - возможность потерь в результате неопределенности рынка, изменения действий контрагента или собственных ошибок.

Коммерческие риски (риски предприятия) - возникают в связи с отклонением ожидаемых результатов деятельности предприятия и, таким образом, связаны с использованием потенциала фирмы.

Риски, связанные с направлением инвестирования, подразделяют на страновые, отраслевые и региональные риски.

К селективным рискам относят риски портфельного инвестирования и временные риски (риск выпуска, покупки или продажи ЦБ в неоптимальное время).

Технологические риски обусловлены применяемой системой торговли и расчетов, зависят от квалификации операторов, надежности технических систем обеспечения. 


\section{Методы анализа рынка ценных бумаг}

Фундаментальный анализ состоит в исследовании корпорацииэмитента, состояния экономики в целом и экономики отрасли, в которой действует корпорация, так как это влияет на изменение курса ЦБ.

Все отрасли условно делятся на три типа: устойчивые, циклические и растущие.

Устойчивые отрасли отличаются стабильностью развития и мало поддаются воздействию макроэкономических факторов. ЦБ компаний, относящихся к устойчивым отраслям, отличаются высокой надежностью, небольшим уровнем риска, но и относительно низкой доходностью.

Показатели деятельности предприятий циклических отраслей, производящих средства производства и товары длительного пользования, тесно связаны с фазами деловой активности.

К числу растущих отраслей относятся традиционные отрасли, переживающие подъем в результате внедрения новых технологий, и отрасли, находящиеся на начальных этапах становления. Помещение средств в компании этих отраслей характеризуется высокой степенью риска и в то же время возможностью получения высоких доходов в короткие сроки.

В фундаментальном анализе считается, что вложения в ЦБ корпораций близки по надежности (степени риска), если близки их показатели платежеспособности и финансовой устойчивости.

Выделяют следующие этапы фундаментального анализа:

1. Общеэкономический, или макроэкономический анализ. Предполагает определение социально-политического и экономического климата инвестиционной деятельности. 
2. Индустриальный анализ - включает изучение делового цикла в экономике, его индикаторов, осуществление классификации отраслей по отношению к уровню деловой активности и по стадиям развития, а также качественный анализ развития отрасли.

3. Анализ конкретного предприятия (фирмы) - состояние и перспективы менеджмента, финансовое состояние.

4. Моделирование цены ЦБ.

Технический анализ - это совокупность методов анализа динамики котировок отдельных ЦБ и всего рынка в целом на основе постоянно изменяющегося спроса и предложения.

Цель теханализа - в определении степени и формы зависимости между ценовыми изменениями в прошлом и будущем и возможном предсказании на ее основе роста или падения курса как отдельных ЦБ, так и рынка в целом.

Технический анализ базируется на трех базовых принципах:

- принципе отражения, означающем, что все происходящие события (экономические, политические, социальные, психологические) находят свое отражение в ценах;

- принципе тренда, согласно которому изменения цен происходят в соответствии с определенным преобладающим направлением;

- принципе повторяемости, суть которого в выявлении модельных ситуаций, появляющихся время от времени на рынке.

Технический анализ применяют для решения следующих задач:

- прогнозирования уровня цен;

- определения оптимального времени покупки или продажи ЦБ;

- проверки достоверности и полноты результатов фундаментального анализа. 
При анализе гистограмм выделяют характерные моменты, называемые “разрывами”, когда нижняя цена предшествующего дня оказывается выше верхней последующего дня или наоборот. При этом различают разрывы четырех видов: обыкновенные, беглые, отрывные и окончательные.

Обыкновенному разрыву присущи низкий объем сделок и отсутствие предшествующей тенденции к росту или подъему цен. Беглый разрыв идет на фоне медленного тренда и среднего уровня объемов. Отрывной разрыв сопровождается ажиотажным спросом и увеличением объема сделок, окончательный следует за отрывным, но при резком снижении спроса.

Методы технического анализа позволяют достичь приемлемого уровня достоверности оценок курсов ценных бумаг.

Для определения ценовых трендов на рынке акций используется теория Доу, которая основывается на использовании двух рыночных индексов: Dow Jones Industrial Average и Dow Jones Transportation Average.

Теория случайного движения отрицает правдивость как технического, так и фундаментального анализа.

\section{Биржевые индексы}

Биржевые индексы обычно рассчитываются как взвешенная среднеарифметическая величина, определяемая с учетом не только относительного изменения, но и абсолютной цены акций компаний, образующих корзину индекса.

Индекс Доу-Джонса представляет собой систему из четырех самостоятельных индексов: промышленного, транспортного, коммунального и комплексного. Каждый из этих индексов формируется на основе цен на акции компаний-лидеров соответствующих отраслей экономики на Ньюйоркской фондовой бирже. 
Наиболее известен промышленный индекс Доу-Джонса. При вычислении значения индекса суммируются курсы акций 30 наиболее крупных промышленных компаний, достаточно репрезентативно отражающих биржевую конъюнктуру. Список промышленных компаний, используемый при исчислении индекса Доу-Джонса, обновляется. При внесении в список учитываются различные критерии. Прежде всего, это крупные корпорации с устойчивым доходом, значительным акционерным капиталом и ведущим положением в том секторе экономики, к которому относится.

Недостатком индекса Доу-Джонса является ограниченность списка охватываемых им компаний, даже в его наиболее широком, “комплексном” варианте. Он оценивает биржевую конъюнктуру на основании акций крупнейших корпораций, которые, как правило, более устойчивы, чем курсы акций менее крупных компаний.

Комплексный индекс Доу-Джонса охватывает акции всех входящих в три других списка компаний (промышленных, транспортных, коммунальных).

Информационная фирма “Стандарт энд Пурз” (S\&P 500) рассчитывает и публикует пять биржевых индексов, более популярен и распространен из которых индекс “Комплексный-500”, объединяющий все эти показатели. Он рассчитывается как отношение текущих рыночных цен на акции в базовый период (1941-1943 гг.), умноженное на 10.

Индекс РТС рассчитывается как отношение суммарной рыночной капитализации ЦБ, включенных в список для расчета индекса, к суммарной рыночной капитализации этих же ЦБ на начальную дату, умноженное на значение индекса на начальную дату и на поправочный коэффициент.

Список ЦБ, используемых для расчета индекса РТС, состоит из наиболее ликвидных акций российских компаний, отобранных Информационным комитетом на основе экспертной оценки. Количество ЦБ в индексе не должно превышать 50. 


\section{Задачи}

1. Текущая рыночная цена акции 1150 руб. За последний год были выплачены дивиденды в размере 120 руб. на 1 акцию. Рассчитайте дивидендную доходность акции.

2. Рыночная цена 12 акций 6000 руб. За последний год были выплачены дивиденды в размере 25 руб. на 1 акцию. Рассчитайте дивидендную доходность акции.

3. Текущая доходность привилегированной акции, по которой при выпуске объявлен дивиденд в $30 \%$, равна $15 \%$; номинальная стоимость 1 руб. Определите рыночную цену акции.

4. Номинальная стоимость акции АО составляет 10 руб. Определить ориентировочную курсовую стоимость акции на рынке ценных бумаг, если известно, что размер дивиденда ожидается на уровне 25\% годовых, а ставка рефинансирования составляет $11 \%$.

5. Номинальная стоимость акции АО составляет 50 руб. Определить ориентировочную курсовую стоимость акции на рынке ценных бумаг, если известно, что размер дивиденда ожидается на уровне $110 \%$ годовых, а ставка рефинансирования составляет $10,5 \%$.

6. Общим собранием акционеров АО принято решение о втором выпуске акций на сумму 150 млн. руб. Первый выпуск акций на сумму 400 млн. руб. оплачен полностью и осуществлялся обыкновенными акциями. Укажите максимально возможную сумму привилегированных акций в объеме второго выпуска.

7. АО осуществлены два выпуска акций: первый в количестве 100000 шт., второй - 1500000 шт., номинальной стоимостью 10 руб. каждая. Первый выпуск размещен по номиналу, второй - по цене размещения, 
в 2 раза, превышающей номинал. Определите размер объявленного уставного капитала АО.

8. Определите конечную доходность акции, если известно, что акция приобретена по номинальной стоимости 1 руб. при ставке дивиденда 80\% годовых. Рыночная стоимость акции через год после выпуска составила 1,8 руб.

9. Дивиденды по акциям компании «Х», номиналом 10 руб., ожидаются в размере 6 руб. на акцию. Требуемая ставка доходности составляет 20\%. Текущий курс акции равен 5. Определить, стоит ли приобретать такие акции.

10.Акция с дивидендом 40\% приобретена по двойному номиналу и продана через год за 136 руб., обеспечив ее владельцу доходность в 56\%. Определите курс акции в момент покупки.

11.Ежегодный дивиденд по привилегированной акции составляет 40 руб. Определить, какой должна быть текущая стоимость этой акции, если приемлемая норма доходности для инвестора равна 20\%.

12.Инвестор продал акцию за 17 руб. и обеспечил доходность в размере 25\%. Какова была бы доходность, если бы инвестор продал акцию на 5 руб. дороже?

13.Акция продается по цене 500 руб. Компания предполагает в конце года выплатить дивиденд в размере 80 руб., а рыночный курс акции к концу года, как ожидается, может составить 550 руб. Определить величину ожидаемой доходности по данной акции.

14.Инвестор приобрел акции номиналом 1 руб. со ставкой дивиденда 10\% годовых. Через два года акции были проданы по цене в четыре раза превышающей номинал. Доходность при этом составила $45 \%$. Определить цену приобретения акций. 
15.У инвестора есть два альтернативных варианта вложений в акции. Акция «А» номиналом 10 руб. продается по курсу 30 руб., выплачиваемый дивиденд составляет 15\%. Акция «Б» имеет номинал 5 руб. и рыночную стоимость 12 руб., а выплачиваемый дивиденд по ней составляет 18\%. Какой вариант вложений более доходный?

16.Инвестор приобрел акции номиналом 2 руб. по курсу 1,5 руб. Дивиденды по акциям в течение всего срока составляли 20\%. Через несколько лет, продав акции по курсу 4 руб., инвестор обеспечил себе доходность в размере 60\%. Определить срок владения акциями.

17.Определить стоимость бессрочной привилегированной акции, дивиденды по которой составляют 7 руб., если получаемый доход равен $12 \%$.

18.Курс акций вырос за год на 20\%, дивиденд выплачивался по полугодиям в размере 15 руб. на акцию. Какова конечная доходность акции за год, если известно, что в конце года ее курс составил 36 руб.

19.Акционерное общество имеет уставный капитал 2000000 руб. (номинальная стоимость акции 10 руб.). Величина объявленных дополнительных обыкновенных акций 115000 шт., из которых размещены 95000 шт. Годовое собрание акционеров принимает решение о выплате годовых дивидендов в сумме 1327500 руб. чистой прибыли АО. Определите величину дивиденда на одну акцию.

20.Уставный капитал АО в размере 1 млн. руб. распределен на 90000 обыкновенных и 10000 привилегированных акций одинакового номинала. Предполагаемый размер прибыли к распределению между акционерами - 200000 руб., фиксированный дивиденд по привилегированным акциям составляет 20\%. Определить, на получение какого дивиденда может рассчитывать в этом случае владелец обыкновенной акции. 
21.Из 25000 эмитированных акций номиналом 10 руб. было размещено 22000, а 3000 остались не проданными. Через год АО выкупило у акционеров 2000 акций. На выплату дивидендов решением собрания акционеров АО решено направить 5 млн. руб. чистой прибыли. Определить сумму дивиденда на одну акцию.

22. Уставный капитал АО составляет 350 млн. руб., в том числе на 300 млн. из обыкновенных акций номиналом 10 руб. и на 50 млн. из привилегированных с 20\% годовых. Определить сумму дивиденда по обыкновенной акции, если на выплату дивидендов направлено 30 млн. руб.

23.Акция номинальной стоимостью 50 рублей со ставкой годового дивиденда $40 \%$ приобретена по двойному номиналу и продана через год, обеспечив ее владельцу 0,9 руб. дохода с каждого инвестируемого рубля. Определить цену продажи акцию.

24.Инвестор приобрел акцию в начале года. Курс акции в первом квартале снизился на $15 \%$ по сравнению с ценой приобретения, во втором квартале повысился на 5\% по сравнению с предшествующим кварталом, в третьем повысился на 25\%, в четвертом на $20 \%$. Определите в годовых процентах доходность инвестора, продавшего акцию в конце четвертого квартала.

25.Инвестор А купил акции по цене 2100 руб. Через 5 дней инвестор А перепродал эти акции инвестору Б. Инвестор Б через 5 дней перепродал эти акции инвестору В по цене 6804 руб. По какой цене инвестор Б купил акции у инвестора А, если известно, что они обеспечили себе одинаковую доходность от проведенных сделок?

26.В инвестиционном портфеле частного инвестора находятся 3 акции $\mathrm{OAO}$ «А», 3 акции ОАО «Б» и 4 акции ОАО «В». Курсовая стоимость акции «Б» в 1,5 раза выше, чем у акции «А», а у акции «В» составляет $80 \%$ от стоимости акции «Б». Как изменится стоимость портфеля, если 
курсы акций «А» и «Б» увеличатся на $10 \%$ и 15\% соответственно, а курсовая стоимость акции «В» упадет на 20\%.

27.Инвестор приобрел 7 акций компании «А», 3 акции компании «Б» и 5 акций компании «В» с равными курсовыми стоимостями. Через три месяца совокупная стоимость указанного пакета акций увеличилась на 40\%. При этом курсовая стоимость акции «В» упала на 50\%, а прирост курса акции «А» оказался в два раза больше, чем прирост курса акции «Б». На сколько процентов увеличился курс акций «Б».

28.Инвестор продал акцию со скидкой в $10 \%$ по сравнению с первоначально назначенной ценой и обеспечил при этом доходность в размере 8\%. Определить, какую доходность обеспечил бы инвестор, если бы продал акцию по первоначальной цене.

29.Облигация номиналом 1000 руб. приобретена по цене 900 руб. Срок обращения облигации - 2 года. Определить доходность облигации к погашению.

30.Инвестор приобрел за 1800 руб. облигацию номиналом 2000 руб. с фиксированным размером дохода $12 \%$. Определите текущий доход по данной облигации.

31.Номинал облигации 100 руб., фиксированная купонная ставка 18\%, рыночная цена облигации 120 руб. Рассчитать текущую доходность облигации.

32.Облигация размещена на первичном рынке по цене 1200 руб., купонный доход составляет ежегодно 60 руб., номинал 1450 руб., срок обращения 3 года. Определить доходность облигации.

33.Облигация номиналом 1000 руб. приобретена по цене 2000 руб. Выплаты процентов по облигации производятся раз в квартал. Определить ставку купонного дохода, если ежеквартально выплаты составляют 100 рублей. 
34.Облигация, выпущенная на 3 года, с купоном 80\% годовых, продается с дисконтом 15\%. Какова ее доходность к погашению?

35.Какова конечная доходность облигации, купленной за 85 руб., при номинале 100 руб., если срок ее обращения 3 года, а купон составляет $10 \%$ годовых?

36.Облигация выпущена на 5 лет. Купон составляет 25\% годовых. Рыночная стоимость облигации составляет $85 \%$ от номинала. Определить текущую доходность.

37.Дисконтная облигация со сроком обращения 92 дня была размещена по цене $88 \%$ от номинала. Определить доходность к погашению, если номинальная стоимость облигации составляет 500 руб.

38.Дисконтная облигация со сроком обращения 92 дня была размещена по цене $88 \%$ от номинала. За 25 дней до погашения облигация была продана по цене 97\% от номинала. Определить доходность к погашению, если номинальная стоимость облигации составляет 500 руб.

39.Определить доходность бескупонной облигации со сроком погашения через 4 года номиналом 1000 руб., приобретенной за 250 руб.

40.Какова текущая доходность облигации с купоном $10 \%$, имеющей рыночную стоимость $90 \%$ от номинала?

41.Определить курс облигации номиналом 1000 руб., если она продается по цене 960 руб.? 1108 руб.?

42.Облигация А размещается на год с дисконтом 40\%, облигация Б размещается по номиналу и имеет купонную ставку $50 \%$, облигация В продается по курсу 80\% при купонной ставке 30\%. Определить, покупка какой облигации предпочтительней, исходя из текущей доходности.

43.Инвестор купил две облигации. По облигации А, номинальной стоимостью 1200 руб., годовой купонный доход составляет 15\%. По 
облигации Б, номиналом 200 долл. США, годовой купонный доход 4\%. При покупке облигации обменный курс составил 22 руб/\$. Через год купонный доход по облигациям был выплачен одновременно. Обменный курс рубля к этому времени упал на $25 \%$. Определить, по какой облигации инвестор получил больший доход в валюте РФ.

44.Облигация со сроком погашения 3 года, с годовыми купонными выплатами 80\% годовых, продается с дисконтом 15\%. Определить ее доходность к погашению.

45.Облигация номиналом 1000 руб. с 5\%-ной купонной ставкой и погашением через 5 лет приобретена на рынке с дисконтом в 10\%. Определить доходность облигации.

46.Определить целесообразность покупки облигации с номиналом 1000 руб. по цене 950 руб. По облигации выплачивается ежегодный купонный доход по ставке 8\%. Срок обращения облигации 3 года. Учтите, что в банке по вкладу на 3 года выплачивается 10\% годовых.

47.АО «А» приобрело за 200 руб. облигацию АО «Б» номинальной стоимостью 100 руб. Выплаты процентов по облигации производятся раз в квартал. Определить величину купонной ставки по облигации (в процентах за год), если ежеквартально на расчетный счет АО «А» в виде процентных платежей поступает 15 руб.

48.Акционерное общество «А» приобрело за 130 p. облигацию акционерного общества «Б» номинальной стоимостью 100 р. Выплаты процентов по облигациям производятся раз в полугодие. Определите величину купонной ставки по облигациям (в процентах за год), если каждое полугодие на расчетный счет $\mathrm{AO}$ «А» в виде процентных платежей по облигации поступает 10 p. 
49.Определить размер дисконта при размещении коммерческим банком своих векселей при условии: вексель выписывается на сумму 100000 руб. со сроком платежа через 240 дней, банковская ставка процента 10,5\%.

50.Вексель с обязательством 12 млн. руб. учитывается банком за 90 дней до погашения с дисконтом 1,04 млн.руб. в пользу банка. Определите величину банковской ставки.

51.Дисконтный вексель выписывается на сумму 1,2 млн. руб. со сроком платежа 90 дней, банковская ставка - 8\% годовых. Определите цену размещения коммерческим банком таких векселей.

52.Вексель на сумму 150000 руб. со сроком оплаты 20 марта выдан 1 декабря. Владелец векселя учел его в банке 10 марта по учетной ставке $11 \%$. Определить доход банка и сумму, полученную по векселю.

53.Определить ориентировочную стоимость векселя номиналом 100000 руб., выпущенного на 184 дня, при условии, что рыночная ставка составляет $15 \%$ годовых.

54.Вексель выписан на 50000 руб. с оплатой через 6 месяцев под 10\% годовых. Определить сумму к получению при наступлении платежа.

55. Вексель на сумму 10000 руб. сроком обращения 180 дней учтен банком за 30 дней до его погашения. Учетная ставка - 11\% годовых. Определить сумму, которую получит обладатель векселя при его исполнении.

56.Вексель приобретен за 125000 руб. Номинал векселя - 100000 руб., срок обращения - 2 года. Определите ставку банка (полугодовую), если бы деньги были размещены на депозит, а не на покупку векселя.

57.Вексель «А», по которому обусловлено начисление процентов, реализуется на рынке по номиналу. Вексель «Б» реализуется с дисконтом $30 \%$ и не имеет процентной ставки. Рассчитать процентную ставку по векселю «А», чтобы обеспечить своему владельцу 
одинаковый доход с векселем «Б». Вексельная сумма векселя «А» в два раза больше вексельной суммы векселя «Б».

58.Номинал коммерческого векселя 1000 ден.ед., срок обращения 3 месяца, дисконтная ставка 15\% годовых. Рассчитать, с каким дисконтом вексель будет учтен банком.

59.Простой вексель на сумму 14000 руб., выданный 9 апреля текущего года на 90 дней, учитывается коммерческим банком 10 мая по ставке 8\%. Определить, какую сумму получит векселедержатель при учете векселя в банке и каков доход банка.

60.Сберегательный сертификат приобретен инвестором за 100000 руб. и погашен через 3 года за 135000 руб. Определить ставку процента по сертификату.

61.Сберегательный сертификат приобретен инвестором за 150000 руб. и погашен через 2 года за 180000 руб. Определить ставку процента по сертификату.

62.Депозитный сертификат, сроком обращения 210 дней, обеспечивает держателю доход в размере 9\% от суммы погашения. Определить размер процентной ставки.

63.Номинал сертификата 170000 руб., процентная ставка 11\%, срок обращения год. Определить сумму, которую получит инвестор при погашении сертификата.

64.Номинал сертификата 90000 руб., процентная ставка 10\%, срок обращения 184 дня. Определить сумму, которую получит инвестор при погашении сертификата.

65.По сберегательному сертификату номиналом 11000 руб., процентной ставкой $12 \%$ годовых сумма погашения составила 13000 руб. Определить срок, на который выдан сберегательный сертификат. 
66. Номинал облигации 500 руб., купонная ставка 10\% годовых, купонный период составляет 92 дня. Рассчитать накопленный купонный доход, если облигация продается за 11 дней до выплаты купона.

67.Номинал облигации 1000 руб., купонная ставка 15\% годовых, купонный период с 15.07.2011г. по 13.01.2012г. Облигация продается 27 декабря 2011г. Рассчитать накопленный купонный доход на дату продажи.

68.Определить доходность ГКО к погашению сроком обращения 12 месяцев, приобретенной на 100-й день периода обращения по цене $90 \%$.

69.Инвестор приобрел ГКО сроком обращения 6 месяцев на 111 день периода обращения по цене $89 \%$. Определить доходность облигации к погашению.

70.Определить по какой цене необходимо купить ГКО за 50 дней до погашения, чтобы инвестор обеспечил себе доходность 25\%. Срок обращения 1 год.

71.ГКО приобретена инвестором на 15-й день периода обращения по цене $76 \%$ и продана на 42-й день по цене 86\%. Определить доходность операции инвестора.

72.ГКО сроком обращения 92 дня приобретена инвестором на 19-й день периода обращения с дисконтом $23 \%$ и продана на 77 -й день по цене 91\%. Определить доходность операции инвестора.

73.ГКО приобретена инвестором на 46-й день периода обращения по цене 81\% и продана на 112-й день с дисконтом 9\%. Определить доходность операции инвестора.

74.ГКО со сроком обращения 6 месяцев размещается по цене $80 \%$. Определить, по какой цене имеет смысл приобрести на вторичном 
рынке ГКО, погашаемые через 2 месяца, чтобы годовая доходность по обеим облигациям была одинакова.

75.Цена 100 кг биржевого актива составляет 10 руб. Банковский процент на 6 месяцев - 11\% годовых. Определить ориентировочную стоимость фьючерсного контракта.

76.Определить цену фьючерсного контракта на доллар США, если процент по трехмесячному депозиту в США составляет 6\%. Курс доллара текущий.

77.Инвестор приобрел опцион на покупку акции с ценой исполнения 20 руб. Премия составила 3 руб. На момент исполнения сделки курс акции составил 22 руб. Определить, прибыль или убыток получил инвестор.

78.Надписатель продал опцион на покупку акции с ценой исполнения 30 руб. Полученная им премия составила 4 руб. На момент исполнения опциона курс акции составил 27 руб. Определить, прибыль или убыток получил надписатель.

79.Инвестор приобрел опцион колл на акцию с ценой исполнения 120 руб. Премия составила 10 руб. На момент исполнения сделки курс акции составил 140 руб. Определить, прибыль или убыток получил продавец опциона.

80.Продавец реализует опцион колл на акцию компании «А» с ценой исполнения 30 руб. Цена за опцион составляет 4 руб. На момент исполнения опциона курс акции составил 32 руб. Определить, прибыль или убыток получил покупатель опциона.

81.Цена страйк по валютному опциону 24,1 руб. за доллар США с исполнением через 3 месяца. Опционный лот 1000 долл. Опционная премия для опциона с таким страйком равна 0,1 руб. с доллара. Рассчитать доход по длинной позиции по колл-опциону, если к моменту исполнения опциона рыночный курс доллара равен: 
- 24,5 руб. за доллар США;

- 24,1 руб. за доллар США;

- 23,7 руб. за доллар США.

82.Рассчитать доход по короткой позиции, открытой по колл-опциону в задаче 60.

83.Рассчитать доход по длинной позиции, открытой по пут-опциону в задаче 60.

84.Рассчитать доход по короткой позиции, открытой по пут-опциону в задаче 60.

85.Участник срочного рынка открыл длинную позицию по фьючерсному контракту на поставку 100 акций через 3 месяца по цене 30 руб. за акцию. Одновременно он открыл короткую позицию по этому же фьючерсу на поставку 100 акций через 3 месяца по цене 31 руб. Рассчитать доходы (убытки) участника срочного рынка, если в момент исполнения контракта рыночная цена акции равна:

- 32 руб.;

- 30 руб.;

- 28 руб.

86.Размер лота валютных опционов равен 100 долл. США, текущий курс 29 руб. за 1 доллар. Рассчитать доход покупателя:

- колл-опциона со страйком 27,0 руб. за доллар и опционной премией 2 руб.;

- пут-опциона со страйком 27,0 руб. за доллар и опционной премией 1,5 руб.

87.Подписная цена на новые акции равна 75 руб., а рыночная цена 78 руб. Для покупки одной акции требуется 10 прав. Определите цену преимущественного права подписки. 
88.Подписная цена на новые акции равна 54 руб., а рыночная цена 49 руб. Для покупки одной акции требуется 5 прав. Определите цену преимущественного права подписки.

89.Рыночная цена акции составляет 4508 руб. за штуку, цена подписки на акции по варранту 4450 руб., на 1 варрант можно купить 5 акций. Определите стоимость варранта.

90.Рыночная цена акции составляет 1,90 руб., цена подписки на акции по варранту 1,88 руб., на 1 варрант можно купить 100 акций. Определите стоимость варранта. 


\section{Примеры решения задач}

1. Определить ориентировочную курсовую стоимость акции на рынке ценных бумаг, если известно, что по ней ожидается дивиденд в размере 50 руб., а ставка рефинансирования составляет $12 \%$.

Решение: используя формулу расчета цены акции $Ц_{\mathrm{a}}=\frac{D}{S} * 100$, где D сумма дивиденда, S - ставка ссудного процента, получим: $Ц_{\mathrm{a}}=50 / 12 * 100=416,7$ руб.

2. Уставный капитал общества составляет 200 млн. руб. Определить, какую сумму составляют привилегированные акции, если известно, что их выпущено максимально возможное количество.

Решение: так как максимально допустимая доля уставного капитала, сформированного привилегированными акциями, составляет $25 \%$, 200 млн.руб. *25/100 = 50 млн.руб.

3. Определить сумму, которую получит инвестор при погашении сертификата, если номинал сертификата 100000 руб., процентная ставка 12\% годовых, срок обращения 184 дня.

Решение: используем формулу суммы, получаемой держателем при погашении:

$\mathrm{S}=\mathrm{N} *(1+\mathrm{R} * \mathrm{t} / 360)$

где $\mathrm{N}$ - номинал сертификата, $\mathrm{R}$ - годовая процентная ставка, начисляемая по сертификату, $\mathrm{t}$ - время обращения сертификата.

$\mathrm{S}=100000 *(1+0,12 * 184 / 360)=106133,33$ руб.

4. Облигация размещена на первичном рынке по цене 1550 руб., ежегодная купонная ставка 25\%, номинал 1500 руб., срок обращения 5 лет. Определить конечную доходность облигации.

Решение: используем формулы конечной доходности облигации и расчета суммы купонного дохода: 
$Д_{\mathrm{x \kappa}}=\frac{\sum B_{i}+\left(L_{1}-L_{0}\right)}{L_{0} * T} * 100$,

где $\Sigma \mathrm{B}_{\mathrm{i}}$ - сумма купонных выплат; $\bigsqcup_{1}, Ц_{0}$ - цены продажи и покупки облигации соответственно; Т - период владения облигацией.

$\mathrm{B}=\mathrm{N} * \mathrm{k} / 100$,

где $\mathrm{N}$ - номинал облигации, $\mathrm{k}$ - ставка купона, \%.

$\Sigma \mathrm{B}_{\mathrm{i}}=1500 * 25 / 100 * 5=1875$ руб.

$Д_{\mathrm{xк}}=(1875+(1500-1550)) /(1550 * 5) * 100=23,55 \%$.

5. Срок обращения облигации 2 года, ставка купона 18\% годовых. Облигация продается с дисконтом 15\%. Рассчитать ее доходность к погашению.

Решение: используем формулу конечной доходности облигации, учитывая, что цена покупки облигации составляет $(1-0,15) * \mathrm{~N}=0,85 * \mathrm{~N}$ (где $\mathrm{N}-$ номинал облигации), размер купонных выплат в год составляет $0,18 * \mathrm{~N}$, a цена продажи облигации соответствует номиналу облигации - N. Таким образом,

$Д_{\text {хк }}=\frac{0,18 * N * 2+(N-0,85 * N)}{0,85 * N * 2} * 100=30 \%$ годовых

6. Определить доходность бескупонной облигации со сроком погашения через 2 года номиналом 500 руб., приобретенной за 400 руб.

Решение: используем формулу доходности бескупонной облигации:

Дбо $_{\text {б }}=\sqrt[n]{\frac{N}{L_{0}}}-1$

$Д_{\text {бо }}=\sqrt{\frac{500}{400}}-1=0,118$ или $11,8 \%$.

7. С каким дисконтом размещается коммерческим банком вексель на сумму 100000 руб. со сроком платежа через 165 дней, если банковская ставка $8 \%$.

Решение: используем формулу расчета дисконта векселя: 
$\mathrm{D}=\frac{N * t * r}{T * 100}$

где $\mathrm{N}$ - номинал векселя, $\mathrm{t}$ - время, оставшееся до погашения векселя; $\mathrm{r}-$ банковская ставка; Т - годовой период.

$\mathrm{D}=100000 * 165 * 8 /(365 * 100)=3616$ руб.

8. Рассчитать купонный доход по облигации номиналом - 500000 руб., купонный период с 10.10.2010г по 15.03.2011г., купонная ставка составляет 9\% годовых. Определить так же накопленный купонный доход по облигации на 28.02.2011г.

Решение: воспользуемся формулами расчета размера купона (С) и накопленного купонного дохода (А):

$\mathrm{C}=\frac{R}{100} * \frac{T}{365} * N$

где R- купонная ставка; T - купонный период, дней; N - номинал облигации.

$\mathrm{A}=\frac{C}{T} *(T-t)$,

где $\mathrm{t}$ - срок в днях до выплаты по купону.

$\mathrm{C}=9 / 100 * 156 / 365 * 500000=19233$ руб.

$\mathrm{A}=19233 / 156 *(156-15)=17384$ руб.

9. Инвестор приобрел ГКО сроком обращения 6 месяцев на 120-й день периода обращения по цене 92\%. Определить доходность облигации к погашению, если ставка налога $15 \%$.

Решение: воспользуемся формулой расчета доходности дисконтных облигаций (ГКО) к погашению:

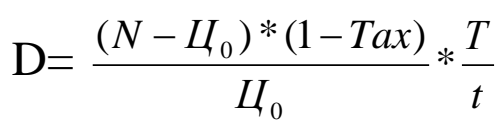

где D - доходность; N - номинал облигации в рублях; Ц 0 - цена покупки облигации; Тах - налоговая ставка на дисконтный доход (в долях единицы); $\mathrm{T}$ - количество дней в году; $\mathrm{t}$ - срок до погашения облигации в днях.

$\mathrm{D}=((1-0,92) *(1-0,15)) / 0,92 * 365 /(365 / 2-120)=0,43$ или 43\%. 
10. ГКО сроком обращения 92 дня приобретена инвестором на 26-й день периода обращения с дисконтом 23\% и продана на 68 -й день по цене 91\%. Определить доходность операции инвестора.

Решение: используем формулу расчета доходности ГКО к вторичным торгам: $\mathrm{D}=\frac{\left(L_{1}-L_{0}\right) *(1-\operatorname{Tax})}{L_{0}} * \frac{T}{\Delta}$

где Ц ${ }_{1}$ - цена продажи облигации на вторичном рынке; $\Delta$ - количество дней между датой приобретения и датой продажи облигации. $\mathrm{D}=((0,91-(1-0,23)) *(1-0,15)) /(1-0,23) * 365 /(68-26)=1,34$ или $134 \%$. 11. Цена акции ОАО 100 руб. Банковский процент - 20\% годовых. Средний размер дивидендов - 10\%. До окончания срока фьючерсного контракта остается 60 дней. Определить ориентировочную стоимость фьючерсного контракта.

Решение: используем формулу стоимости фьючерсного контракта для биржевого актива, приносящего доход:

$$
L=L_{1}+L_{1} *(R-d) * \frac{t}{360}
$$

где Ц ${ }_{1}$ - рыночная цена актива (спот); $\mathrm{R}$ - банковский процент по депозитам в долях единицы; $\mathrm{t}$ - число дней до окончания срока действия фьючерсного контракта; d - ставка дивиденда или процентов в долях единицы.

$Ц=100+100 *(0,2-0,1) * 60 / 360=101,67$ руб.

12. Инвестор приобрел опцион на покупку 100 акций с ценой исполнения 50 руб. Премия составила 5 руб. На момент исполнения сделки курс акции составил 47 руб. Определить, прибыль или убыток получил инвестор.

Решение: покупатель колл-опциона получает доход, если выполняется неравенство:

$$
P>\Pi+\frac{\underline{L}}{K}
$$


где Р — рыночная цена на акции на дату окончания контракта; П — цена на акции, назначенная в опционном контракте (цена-страйк); К - количество акций по опционному контракту; Ц - цена покупки опциона (опционная премия).

$47>50+\frac{5}{100}-$ неверно, таким образом, инвестор получил убыток.

13. Надписатель продал опцион на продажу 100 акций с ценой исполнения 120 руб. Полученная им премия составила 20 руб. На момент исполнения опциона курс акции составил 165 руб. Определить, прибыль или убыток получил надписатель опциона.

Решение: продавец пут-опциона получает доход, если выполняется неравенство:

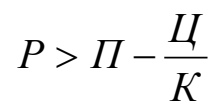

$120>120-\frac{20}{100}$ - верно, таким образом, надписатель получил прибыль.

14. Инвестор приобрел опцион на продажу 100 акций с ценой исполнения 50 руб. Премия составила 5 руб. На момент исполнения сделки курс акции составил 40 руб. Определить, какую прибыль (убыток) получил инвестор.

Решение: доход покупателя пут-опциона рассчитывается по формуле:

$Д_{p}=(\Pi-P) * K-Ц$

$Д_{\mathrm{p}}=(50-40) * 100-5=5$.

Таким образом, инвестор получил прибыль 995 руб.

15. Надписатель продал опцион на покупку 100 акций с ценой исполнения 30 руб. Полученная им премия составила 4 руб. На момент исполнения опциона курс акции составил 27 руб. Определить, какую прибыль или убыток получил надписатель опциона.

Решение: доход продавца колл-опциона рассчитывается по формуле:

$Д_{c}^{\prime}=(\Pi-P)^{*} K+Ц$ 
$Д^{\prime}{ }_{\mathrm{c}}=(30-27) * 100+4=304$.

Так как доход продавца опциона ограничивается премией, он получил прибыль 4 руб.

16. Подписная цена на новые акции равна 105 руб., а рыночная цена 106 руб. Для покупки одной акции требуется 5 прав. Определите цену преимущественного права подписки.

Решение: стоимость права на подписку рассчитывается по формуле:

$L=\frac{P-\Pi}{K}$

где P - рыночная цена старых акций за штуку; П - цена подписки на новые акции; К - количество старых акций, дающих право подписаться на одну новую акцию.

$Ц=(106-105) / 5=0,2$.

17. Рыночная цена акции составляет 106 руб. за штуку, цена подписки на акции по варранту 105 руб., на 1 варрант можно купить 10 акций. Определите стоимость варранта.

Решение: используем формулу определения стоимости варранта:

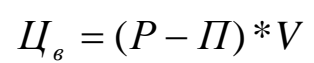

где Р - рыночная цена старых акций; П - цена акции, назначенная по варранту; V - количество акций, которые можно купить на 1 варрант. $\bigsqcup_{\mathrm{B}}=(106-105) * 10=10$. 


\section{Тесты}

1. Фондовый рынок является частью рынка:
а) финансового;
б) денежного;
в) реальных активов;
г) капиталов;
д) банковских кредитов.

2. Стихийным является рынок:

а) испытывающий внезапные стихийные колебания (падения или подъемы) курсов ценных бумаг;

б) функционирующий без всяких правил: правил доступа ценных бумаг и участников к торгам, механизма торговли, установления цен;

в) "уличный", на котором торгуют ценными бумагами, не котирующимися на бирже.

3. Рынок ценных бумаг является составной частью:

а) финансового рынка;

б) рынка кредитных ресурсов;

в) рынка межбанковских кредитов.

4. Рынок, на котором происходит продажа акций их первым владельцам, называется:
а) первичным;
б) вторичным;
в) уличным.

5. К ценным бумагам в соответствии с российским законодательством относятся:

а) акция;

б) депозитная расписка; 
в) именная сберегательная книжка;

г) сберегательная книжка на предъявителя.

6. Различия между документарными и бездокументарными ценными бумагами состоят:

а) в объеме прав, предоставляемых ценной бумагой;

б) в способе фиксации-прав, закрепляемых ценной бумагой.

7. Что из перечисленного не относится к ценным бумагам:

a) акции и облигации;

б) страховые полисы;

в) депозитный сертификат;

г) варрант.

8. В зависимости от вида носителя документа ценные бумаги могут выпускаться:

а) на бумажных носителях;

б) в форме записей на счетах депо;

в) в форме пластиковых карточек.

9. Что понимается под ликвидностью ценной бумаги:

а) регулярное получение дохода;

б) возможность использования в качестве залога;

в) возможность быстрой продажи без существенных потерь в стоимости;

г) возможность получения дохода при ликвидации эмитента.

10. Что является сертификатом ценной бумаги:

а) документ, выпускаемый эмитентом и удостоверяющий совокупность прав на указанное в сертификате количество ценных бумаг;

б) ценная бумага - свидетельство владения поименованными в ней лицами определенным количеством ценных бумаг;

в) справка - свидетельство владения поименованным в ней лицом определенным количеством ценных бумаг. 
11. По открытой подписке могут размещаться акции:

a) открытого АO;

б) закрытого AO.

12. Акционеры - владельцы привилегированных акций участвуют в общем собрании акционеров с правом голоса при решении вопросов:

а) об открытии филиалов и представительств;

б) о реорганизации $\mathrm{AO}$;

в) о выплате дивидендов по привилегированным акциям;

г) о выборе руководящих органов АО;

д) о ликвидации АО.

13. На собственные акции АО, находящиеся в его распоряжении, дивиденды:

а) начисляются;

б) не начисляются.

14. Кумулятивные акции - это:

а) акции, обеспечивающие избрание в совет директоров АО;

б) привилегированные акции, по которым невыплаченный дивиденд накапливается и выплачивается в дальнейшем;

в) акции, дающие право на кумулятивную систему голосования на общем собрании акционеров.

15. При прочих равных условиях курсовая стоимость акций в случае повышения банковских ставок по депозитам:

а) понижается;

б) повышается;

в) остается прежней.

16. Определите разницу между открытым и закрытым акционерными обществами:

а) ОАО свободно реализует свои акции всем желающим; 
б) ЗАО вообще не реализует свои акции на рынке;

в) $3 \mathrm{AO}$ дает своим акционерам право продажи принадлежащих им акций только по разрешению Совета директоров;

г) юридической разницы между ними вообще не существует.

17. Какой может быть доля привилегированных акций в общем объеме уставного капитала акционерного общества:

а) не должна превышать $10 \%$;

б) не должна превышать 25\%;

в) не должна превышать $50 \%$;

г) определяется уставом общества.

18. Номинальная стоимость всех акций АО составляет:

a) рыночную стоимость $\mathrm{AO}$;

б) собственный капитал $\mathrm{AO}$;

в) уставный капитал АO.

19. Номинальная стоимость одного типа привилегированных акций акционерного общества может быть:

а) одинаковой;

б) различной.

20. Величину уставного капитала акционерного общества составляет: a) сумма номинальных стоимостей всех обыкновенных акций;

б) сумма рыночной стоимости всех обыкновенных акций и привилегированных акций одного типа;

в) сумма номинальных стоимостей всех размещенных обыкновенных акций и привилегированных акций одного типа;

г) сумма рыночной стоимости всех размещенных обыкновенных и привилегированных акций.

21. При учреждении акционерного общества оплата акций учредителями может производиться по цене: 

а) номинальной;
б) ниже номинальной;
в) номинальной и ниже номинальной.

22. Акционер за результаты хозяйственной деятельности акционерного общества несет ответственность:

а) ограниченную его долей в уставном капитале общества;

б) всем принадлежащим ему имуществом.

23. Обязательно ли включение в реквизиты сертификата акции имени ее владельца:

а) не обязательно, если она является ценной бумагой на предъявителя;

б) не обязательно, если она является эмиссионной ценной бумагой;

в) обязательно.

24. Эмиссионный доход АО это:

а) разница между номинальной стоимостью акции и ценой ее фактической продажи на вторичном рынке;

б) доход от продажи акций при первичной эмиссии по ценам выше номинала;

в) доход от продажи акций, который получает посредник, осуществляющий размещение акций на основе договора с эмитентом.

25. Доход акционера, выраженный в процентах к стоимости акции, это:
а) дисконт;
б) дивиденд;
в) дизажио.

26. Объявленные акции - это:

а) акции, намерения о выкупе которых у акционеров объявило акционерное общество;

б) акции, которые компания вправе разместить дополнительно к размещенным ранее. 
27. При эмиссии акций АО было заявлено, что предполагаемый размер дивиденда по обыкновенным акциям составит 30\%. По итогам года Совет директоров рекомендовал выплачивать дивиденды в размере 15\% годовых. Каким образом акционеры могут обеспечить выплату дивидендов в размере $30 \%$ ?

a) принять соответствующее решение общего собрания акционеров;

б) обратиться в судебные органы;

в) в данном случае обеспечить выплату дивидендов в размере $30 \%$ нельзя.

28. Размер дивидендов по обыкновенным акциям рассчитывается как:

a) фиксированный процент по отношению к курсовой стоимости акций на дату выплаты дивидендов;

б) частное от деления чистой прибыли АО на количество акций;

в) частное от деления балансовой прибыли АО на количество акций.

29. Контрольный пакет акций это:

а) форма участия в капитале предприятия, которая обеспечивает безусловное право принятия или отклонения решений на собрании акционеров и в органах управления компанией;

б) форма участия в капитале предприятия, которая обеспечивает безусловное право принятия или отклонения решений в органах управления компанией;

в) пакет акций стоимостью 51 \% уставного капитала АО.

30. Размер промежуточного дивиденда по обыкновенным акциям АО устанавливает:

а) совет директоров;

б) общее собрание АO;

в) общее собрание акционеров при выпуске акций.

31. Может ли АО выпускать обыкновенные акции различной номинальной стоимости:

a) может, если акции не предоставляют право голоса; 
б) не может;

в) может, если осуществляется дополнительная эмиссия.

32. Является ли выписка из реестра акционеров ценной бумагой:

а) не является;

б) является.

33. Облигация является:

а) долговым обязательством инвестора перед эмитентом;

б) долговым обязательством эмитента перед инвестором;

в) документом, удостоверяющим право собственности инвестора на часть имущества эмитента.

34. Облигации право на участие в управлении эмитентом:

а) дают, если это право предусмотрено условиями эмиссии;

б) дают;

в) дают, если это записано в уставе;

г) не дают.

35. В России облигации могут выпускаться:

а) именные и на предъявителя;

б) только именные;

в) только на предъявителя.

36. Проценты по корпоративным облигациям устанавливаются:

а) по отношению к курсовой стоимости облигации на дату, официально объявленную АО;

б) по отношению к номиналу облигации независимо от их курсовой стоимости;

в) по отношению к цене, по которой производилось размещение облигаций.

37. Инвестор покупает с дисконтом облигацию с купоном 100\% годовых и держит ее до погашения. Какой уровень доходности до погашения не может иметь данная облигация: 

a) 140\% годовых;
б) $80 \%$ годовых;
в) $220 \%$ годовых.

38. Если доходность до погашения по облигации $\mathrm{X}$ равна ее доходности по купону, облигация продается по цене:
a) меньше номинала;
б) по номиналу;
в) больше номинала.

39. Вексель эмиссионной бумагой:
а) является;
б) не является.

40. Если суммы простого векселя, обозначенные прописью и цифрами, отличаются, то в этом случае вексель:
а) имеет силу лишь на меньшую сумму;
б) недействителен;
в) имеет силу на сумму, обозначенную прописью.

41. Простой вексель - это:

а) обязательство векселедателя, обусловленное договором купли-продажи товаров, выплатить по наступлению предусмотренного векселем срока полученные взаймы денежные суммы;

б) ничем не обусловленное денежное обязательство векселедателя выплатить по наступлению предусмотренного векселем срока полученные взаймы денежные суммы.

42. Надежность векселя при наличии аваля:
а) понижается;
б) повышается;
в) остается без изменений.

43. Индоссамент может быть оформлен: 
а) на самом векселе;

б) в отдельном документе, например, в приложении к договору покупки/продажи векселя;

в) на добавочном листе, прикрепленном к векселю.

44. Если индоссамент не содержит наименования лица, в пользу которого он совершен, то:

а) вексель становится документом на предъявителя;

б) индоссамент является недействительным;

в) вексель становится долговой распиской, поскольку такой индоссамент ведет к дефекту формы векселя.

45. В индоссаменте:

а) указываются условия, при которых будет осуществлен платеж по векселю;

б) не указываются условия, при которых будет осуществлен платеж по векселю.

46. Индоссамент на часть вексельной суммы осуществлен быть:

a) может;

б) не может.

47. Если в векселе не указан срок платежа, то он должен быть оплачен:

а) по предъявлении;

б) в течение года с даты составления.

48. При отсутствии в векселе указания на место платежа таковым является:

а) банк, обслуживающий плательщика;

б) место, обозначенное рядом с наименованием плательщика.

49. Если в векселе не указано место его составления, то считается, что он составлен в месте, обозначенном рядом с наименованием:

а) векселедателя;

б) акцептанта. 
50. Как называется индоссамент, совершенный на ценной бумаге, с указанием лица, которому должно быть произведено исполнение:

а) бланковый;

б) именной;

в) правильных ответов нет.

51. Несоответствие между суммами, написанными в векселе прописью и цифрами, приводит к утрате вексельной силы.
а) да;
б) нет.

52. Лицо, передающее право по векселю, называется:

a) индоссатом;

б) индоссантом;

в) авалистом.

53. Что вы понимаете под дисконтированием векселя:

а) дисконтирование векселя - это его покупка у владельца до наступления срока платежа по нему по цене, большей, чем указана в векселе;

б) дисконтирование векселя - это его покупка у владельца до наступления срока оплаты векселя по цене, меньшей той суммы, которая должна быть выплачена по нему в конце срока.

54. Какие показатели необходимо знать, чтобы рассчитать сумму учетного процента (дисконта) по векселю при условии, что в году 365 дней:
а) сумму векселя;
б) дату составления векселя;
в) срок до наступления платежа по векселю (в днях).

55. В случае, если одна из подписей на векселе будет признана подложной, то вексель:

а) недействителен;

б) действителен. 
56. Гарантийная надпись на векселе (вексельное поручительство) называется:
а) акцепт;
б) аваль;
в) аллонж.

57. Согласие плательщика на оплату векселя называется:
а) акцепт;
б) аваль;
в) индоссамент;
г) домицилиация.

58. Передаточная надпись на векселе называется:
а) индоссамент;
б) аваль;
в) аллонж;
г) дисконт.

59. К обязательным реквизитам векселя не относятся:

а) указание срока платежа;

б) простое и ничем не обусловленное обязательство либо требование заплатить определенную сумму;

в) указание места платежа;

г) наименование и подпись плательщика по переводному векселю;

д) наименование «вексель», включенное в текст документа;

е) указание сделки, послужившей основанием для выписки векселя.

60. Укажите, какие из перечисленных видов индоссаментов удостоверяют переход права собственности вексельной суммы к другому лицу:

а) инкассовый;

б) залоговый;

в) именной; 
г) бланковый.

61. Вексель, в котором не указан срок платежа, считается подлежащим оплате:

а) по предъявлении;

б) по предъявлении, не ранее 31 дня от даты составления;

в) не ранее, чем через 365 дней от даты составления;

г) считается недействительным и может не оплачиваться;

д) не позднее, чем через 365 дней от даты составления.

62. Государство как участник рынка ценных бумаг выполняет следующие функции:

a) создает нормативные акты, регулирующие выпуск и обращение ценных бумаг и контролирует их исполнение;

б) устанавливает предельные цены при первичном размещении эмитентами ценных бумаг;

в) является эмитентом ценных бумаг.

63. В России к государственным ценным бумагам относятся ценные бумаги:

а) приватизированных предприятий;

б) субъектов РФ;

в) федеральные;

г) банков с государственным участием.

64. От каких факторов зависит доходность облигаций:
а) качество эмитента;
б) ликвидность;
в) «популярность»;
г) срок погашения;
д) налоговые правила. 
65. Долговые обязательства правительства РФ к составу внутреннего долга:

а) относятся;

б) не относятся.

66."Ставка без риска" - это ставка:

а) доходности по облигациям самых надежных частных эмитентов;

б) доходности по краткосрочным обязательствам государства;

в) по депозитам в коммерческих банках.

67. Доходность государственных ценных бумаг в сравнении с доходностью корпоративных облигаций:

a) выше;

б) ниже;

в) одинакова для всех рыночных инструментов.

68.Эмитентом муниципальных ценных бумаг может быть:

a) субъект федерации, в состав которого входит конкретное муниципальное образование;

б) орган местного самоуправления;

в) исполнительный орган местного самоуправления, осуществляющий указанную функцию в порядке, установленном законодательством РФ и уставом муниципального образования.

69. На фондовом рынке «быками» называются спекулянты, играющие на бирже:

a) на повышение курсовой стоимости базисных активов;

б) понижение курсовой стоимости базисных активов.

70. На фондовом рынке «медведями» называются спекулянты, играющие на бирже:

а) на повышение курсовой стоимости базисных активов;

б) понижение курсовой стоимости базисных активов. 
71.Фьючерсная сделка:

а) обязательна только для покупателя;

б) обязательна для исполнения обеих сторон в сделке;

в) обязательна только для продавца.

72."Длинная" позиция по фьючерсному контракту - это:

а) покупка контракта на любой срок;

б) продажа контракта на любой срок;

в) покупка или продажа контракта на длительный период времени.

73."Короткая" позиция представляет собой:

а) заключение обратной сделки по фьючерсному контракту;

б) продажа фьючерсного контракта;

в) покупка или продажа контракта на короткий срок.

74. Фьючерсные контракты стандартизированы по следующим параметрам:

а) срок поставки;

б) цена базисного актива;

в) количество базисного актива.

75. Покупка колл-опциона используется для:

а) игры на повышение;

б) игры на понижение;

в) комбинационной стратегии.

76. Продажа пут-опциона используется для:

а) комбинационной стратегии;

б) игры на понижение;

77. в) игры на повышение.

78.Опцион на покупку - это опцион, дающий право:

а) надписателю опциона купить ЦБ;

б) держателю опциона купить ЦБ. 
79. Опцион на продажу - это опцион, дающий право:

а) надписателю опциона продать ЦБ;

б) держателю опциона продать ЦБ.

80. Надписатель опциона - это:

a) продавец опциона;

б) покупатель опциона;

в) депозитарий, в котором хранится базовый актив опциона;

г) гарант совершения опционной сделки.

81. При покупке опциона на продажу:

а) держатель опциона играет на повышение, надписатель - на понижение;

б) держатель и надписатель играют на повышение;

в) держатель опциона играет на понижение, надписатель - на повышение;

г) держатель и надписатель играют на понижение.

82. При покупке опциона на покупку:

а) держатель и надписатель играют на повышение;

б) держатель и надписатель играют на понижение.

в) держатель опциона играет на повышение, надписатель - на понижение;

г) держатель опциона играет на понижение, надписатель - на повышение;

83. Фиксированная цена, по которой покупатель опциона может реализовать свое право на продажу или покупку базисного актива, называется:

а) страйковая цена;

б) внутренняя стоимость;

в) премия;

г) цена исполнения.

84. К производным финансовым инструментам относятся:

а) фьючерсы;

б) опционы; 
в) сертификаты акций;

г) коносаменты.

85. Открывая длинную позицию по форвардному контракту, участник фондового рынка рассчитывает на:

а) снижение спотовой цены на актив;

б) повышение спотовой цены на актив;

в) неизменность спотовой цены на актив.

86. Открывая короткую позицию по форвардному контракту, участник фондового рынка рассчитывает на:

а) снижение спотовой цены на актив;

б) повышение спотовой цены на актив;

в) неизменность спотовой цены на актив.

87. Какую опционную позицию нужно открыть, если ожидается сильное повышение спотовой цены на актив:

а) длинный пут-опцион;

б) длинный колл-опцион;

в) короткий пут-опцион;

г) короткий колл-опцион;

д) нет правильного ответа.

88. Какую опционную позицию нужно открыть, если ожидается сильное понижение спотовой цены на актив:
а) длинный пут-опцион;
б) длинный колл-опцион;
в) короткий пут-опцион;
г) короткий колл-опцион;
д) нет правильного ответа.

89. Деятельность в качестве инвестора на РЦБ лицензированию:

a) не подлежит; 
б) подлежит.

90. Профессиональными участниками рынка ценных бумаг могут быть:

а) только юридические лица;

б) юридические и физические лица.

91. Физическое лицо на РЦБ может выполнять функции:

а) инвестора;

б) профессионального участника РЦБ;

в) организатора торговли на РЦБ;

г) эмитента.

92. Государственное регулирование деятельности на РЦБ в РФ осуществляется путем:

а) лицензирования деятельности профессиональных участников РЦБ;

б) участия в саморегулируемых организациях;

в) непосредственного управления деятельностью профессиональных участников фондового рынка;

г) аттестации специалистов.

93. ФСФР лицензирует следующие виды профессиональной деятельности на РЦБ:

а) по управлению ценными бумагами;

б) дилерскую;

в) регистраторскую;

г) клиринговую;

д) инвестиционную;

е) эмиссионную.

94. В соответствии с законодательством РФ деятельность по ведению реестра владельцев ценных бумаг с другими видами профессиональной деятельности:

а) совмещается только с депозитарной деятельностью; 
б) не совмещается;

в) совмещается.

95. Коммерческие банки в РФ на основе банковской лицензии могут выступать на РЦБ в качестве:
а) инвестора;
б) депозитария;
в) профессионального участника РЦБ;
г) эмитента.

96. Коммерческие банки в РФ выполнять функции профессиональных участников РЦБ:
a) могут;
б) не могут;
в) могут только после получения лицензии ФСФР.
97.Коммерческий банк быть брокером по операциям с ЦБ право:
a) не имеет;
б) имеет;
в) имеет только после получения лицензии ФСФР.

98. По договору комиссии по операциям с ЦБ брокер действует за счет:

a) собственного капитала или капитала клиента в зависимости от положений договора;

б) клиента;

в) собственного капитала.

99. По договору комиссии по операциям с ЦБ брокер заключает сделки от имени:
a) своего или клиента в зависимости от положений договора;
б) клиента;
в) своего. 
100. Профессиональный участник РЦБ - дилер - котировать ЦБ имеет право:
а) имеет;
б) не имеет.

101. Оказанием услуг по хранению сертификатов ЦБ и (или) учету и переходу прав на ЦБ занимается:
а) депозитарий;
б) клиринговая организация.

102. Депозитарием по российскому законодательству может выступать:

а) как физическое, так и юридическое лицо;

б) только юридическое лицо;

в) только физическое лицо.

103. Лицо, пользующееся услугами депозитария по хранению ЦБ и (или) учету прав на ЦБ, именуется:
а) комитентом по счету депо;
б) депонентом;
в) депозитором.

104. Номинальный держатель ценных бумаг собственником данных ценных бумаг:
а) не является;
б) является;
в) является только в тех случаях, если они приобретены самим номинальным держателем.

105. Деятельность по ведению реестра по российскому законодательству может осуществлять:
а) только юридическое лицо;
б) только физическое лицо; 
в) как физическое, так и юридическое лицо.

106. Держателем реестра акционерного общества должен быть регистратор, если число акционеров превышает:
a) 50 ;
б) 300 ;
в) 500 ;
г) 200 .

107. Фондовая биржа может совмещать свою деятельность с деятельностью:

а) в качестве дилера;

б) по управлению ЦБ;

в) по ведению реестра владельцев ЦБ;

г) по определению взаимных обязательств.

108. Через какие органы осуществляется государственное регулирование фондового рынка в РФ:

а) Федеральная служба по финансовым рынкам;

б) Центральный банк РФ;

в) Министерство юстиции;

г) Пенсионный фонд;

д) Министерство по налогам и сборам РФ;

е) Министерство финансов.

109. Какие из перечисленных характеристик являются названиями типов инвесторов в зависимости от преследуемых целей инвестирования:

а) умеренно-агрессивные;

б) дилетанты;

в) изощренные. 
110. К какому типу инвесторов относится инвестор, вкладывающий свои средства в качественные ценные бумаги, преследуя цель безопасного вложения:

a) консервативные;

б) опытные;

в) агрессивные.

111. Портфель инвестиций АО имеет следующую структуру: облигации государственного займа 20\%; простые акции крупных нефтяных компаний $15 \%$; привилегированные акции банков, страховых компаний $15 \%$; депозитные сертификаты коммерческих банков 15\%; облигации крупных промышленных предприятий 30\%. Определите тип портфеля:

а) консервативный, ориентированный на надежность;

б) агрессивный, ориентированный в большей степени на доходность, нежели на надежность вложений.

112. Какая профессиональная деятельность на РЦБ признается депозитарной:

а) оказание услуг по ведению реестра владельцев ценных бумаг;

б) оказание услуг по хранению сертификатов ценных бумаг и (или) учету прав на ЦБ;

в) оказание услуг по доверительному управлению ценными бумагами для клиентов;

г) предоставление кредитов на покупку ценных бумаг.

113. Какая организация имеет право регистрировать выпуск ценных бумаг иностранными эмитентами в Российской Федерации:

a) Банк России;

б) Министерство финансов РФ;

в) Федеральная служба по финансовым рынкам;

г) Министерство экономики РФ. 
114. В России на фондовых биржах существование различных категорий членства с неравными правами:
а) запрещено;
б) разрешено, если это оговорено в правилах биржи;
в) разрешено.

115. Каковы основные обязанности фондовой биржи:

а) ограничение манипулирования ценами;

б) предоставление заинтересованному лицу списка ценных бумаг, допущенных к торгам;

в) регистрация биржевых сделок;

г) раскрытие информации о деятельности эмитента, чьи ценные бумаги обращаются на бирже;

д) заключение сделок с ценными бумагами.

116. Дайте характеристику стихийного биржевого рынка:

а) отсутствие единого курса ценных бумаг;

б) участие непрофессионалов;

в) множество трейдеров.

117. Из каких элементов состоит процедура допуска ценных бумаг к торгам:
а) листинг;
б) паблисити;
в) предлистинг;
г) делистинг;
д) котировка ценных бумаг.

118. Какие существуют методы котировки ценных бумаг:

а) метод единого курса;

б) регистрационный метод;

в) средневзвешенный метод; 
г) метод максимальных цен при покупке и минимальных цен при продаже;

д) метод минимальных цен при покупке и максимальных цен при продаже.

119. Укажите правильное определение понятия конъюнктуры рынка ценных бумаг:

а) совокупность ценных бумаг, обращающихся на рынке ценных бумаг;

б) совокупность ценовых показателей в отдельный момент времени для бумаг, обращающихся на рынке;

в) совокупность эмитентов и инвесторов - участников рынка ценных бумаг;

г) соотношение между спросом и предложением на ценные бумаги, колеблющееся под влиянием различных экономических и политических факторов.

120. Выберите из списка индексов российские фондовые индексы:
a) RTSE;
б) NIKKEY;
в) S\&P - 500;
г) MICEX;
д) $\mathrm{DJ}$.

121. Может ли иметь место реальная ситуация, в условиях которой значение индекса растет, а курс отдельной ценной бумаги снижается:
а) может;
б) не может.

122. Положительное значение $\beta$-коэффициента свидетельствует о том, что при изменении конъюнктуры рынка доходности ценной бумаги и рынка изменяются:

а) в противоположных направлениях;

б) в одном направлении.

123. Если индекс снижается, а курс отдельной ценной бумаги повышается, то каково значение $\beta$-коэффициента для этой бумаги: 

а) меньше нуля;
б) равно нулю;
в) больше нуля.

124. Если курсовая стоимость акций совершает колебания в том же направлении, что и рынок, то значение показателя $\beta$-коэффициента:
а) больше единицы;
б) меньше единицы;
в) равно единице.

125. Курсовая стоимость акций более неустойчива, чем рынок в целом, при значении показателя $\beta$-коэффициента:
а) больше единицы;
б) меньше единицы;
в) равном единице.

126. Для акций, рыночные цены которых менее волатильны, чем рынок в целом, значение показателя $\beta$-коэффициента:
a) больше единицы;
б) меньше единицы;
в) равно единице.

127. Укажите форму, в которой биржа как организатор торговли на рынке ценных бумаг (не совмещающая деятельность по организации торговли с иными видами деятельности за исключением депозитарной и клиринговой) может быть признана профессиональным участником рынка ценных бумаг.
а) общество с ограниченной ответственностью;
б) товарищество на вере;
в) некоммерческое партнерство;
г) ассоциация;
д) акционерное общество. 
128. Коэффициент бета $(\beta)$ - это мера:

а) рискованности ценной бумаги;

б) эластичности процентного изменения цены акции к процентному изменению рынка;

в) эффективности рыночного портфеля акций;

г) другое.

129. Могут ли ценные бумаги, не прошедшие листинг, быть объектом сделок на фондовой бирже:

а) да, в любом случае;

б) да, в порядке, предусмотренном внутренними документами биржи;

в) нет.

130. Какие реквизиты сертификата эмиссионной ценной бумаги не относятся к обязательным:

а) наименование эмитента и его юридический адрес;

б) вид ценной бумаги;

в) регистрационный номер эмиссионной ценной бумаги;

г) подписи руководителей эмитента и лица, выдавшего сертификат;

д) подписи покупателей.

131. Необходимо ли регистрировать проспект эмиссии эмиссионных ценных бумаг (акций), если общий объем эмиссии составляет 50000 руб. и выпуск распространяется среди заранее известного круга владельцев в количестве 150 человек:

а) необходимо регистрировать;

б) регистрировать не обязательно, так как круг владельцев меньше номинального.

132. Какую информацию о ценных бумагах и финансово хозяйственной деятельности эмитент публично размещаемых ценных бумаг обязан раскрыть: 
a) список акционеров эмитента, владеющих 20\% и более уставного капитала;

б) список акционеров эмитента, владеющих 15\% и более уставного капитала;

в) данные о формировании и использовании резервного и других специальных фондов эмитента;

г) протоколы общих собраний владельцев ценных бумаг эмитента;

д) факты, повлекшие увеличение чистой прибыли или убытков эмитента более, чем на $20 \%$ в течение отчетного квартала.

133. АО с полностью оплаченным уставным капиталом 1000 млн.руб. приняло решение о выпуске облигационного займа на сумму 2000 млн.руб. На момент принятия решения АО убытков не имело. Регистрирующий орган данный выпуск:

а) зарегистрирует;

б) не зарегистрирует.

134. Сколько нужно сертификатов ценных бумаг, чтобы удостоверить право на 15 эмиссионных ценных бумаг с одним регистрационным номером?
а) один сертификат;
б) 15 сертификатов;
в) количество сертификатов, названное покупателем.

135. Тело "японской свечи" черное, если:

а) цена закрытия равна цене открытия;

б) цена закрытия ниже цены открытия;

в) цена закрытия выше цены открытия;

136. Верхняя граница диапазона колебания курса цены бумаги называется уровнем:
а) поддержки;
б) сопротивления;
в) разворота. 
137. Нижняя граница диапазона колебания курса цены бумаги называется уровнем:
а) поддержки;
б) сопротивления;
в) разворота.

138. Тело "японской свечи" белое, если:
а) цена закрытия равна цене открытия;
б) цена закрытия ниже цены открытия;
в) цена закрытия выше цены открытия.

139. Оцените справедливость утверждения: «Доходность вложений в ценные бумаги тем выше, чем выше надежность этих ценных бумаг»:
а) справедливо;
б) несправедливо;
в) справедливо только для акций;
г) справедливо только для долговых обязательств;

д) справедливо только при определенных условиях.

140. Что в соответствии с Гражданским кодексом РФ не относится к ценным бумагам:
а) чек;
б) коносамент;
в) сберегательный сертификат;
г) банковская именная сберкнижка.

141. За счет какого источника производится выплата процентов держателям облигаций АО при удовлетворительном финансовом состоянии:
а) оборотных средств;
б) балансовой прибыли;
в) чистой прибыли;
г) резервного фонда; 
д) банковского кредита.

142. Расположите ценные бумаги в порядке возрастания риска.

a) государственные ценные бумаги, корпоративные облигации, конвертируемые акции, обыкновенные акции, варранты, опционы;

б) конвертируемые облигации, государственные ценные бумаги, корпоративные облигации, обыкновенные акции, варранты, опционы;

в) обыкновенные акции, государственные ценные бумаги, корпоративные облигации, конвертируемые облигации, варранты, опционы.

143. Из ниже перечисленных укажите инвестиции, которые в наибольшей степени подходят для получения текущего дохода:

а) акции венчурных компаний;

б) привилегированные акции первоклассных компаний;

в) банковские депозиты;

г) корпоративные облигации с нулевым купоном;

д) инструменты денежного рынка.

144. Что из перечисленного относится к факторам, оказывающим воздействие на цены акций:

а) процентные ставки;

б) курсы валют;

в) экономические циклы;

г) изменения в предпочтениях потребителей;

д) новые законодательные акты, влияющие на затраты и спрос.

145. Что такое доход акционера, выраженный в процентах к стоимости акции:
а) дисконт;
б) масса дивиденда;
в) ставка дивиденда;
д) ажио. 
146. Может ли снижаться текущая доходность привилегированной акции, дивиденд по которой носит фиксированный характер:
а) да;
б) нет. 


\section{Кроссворды}

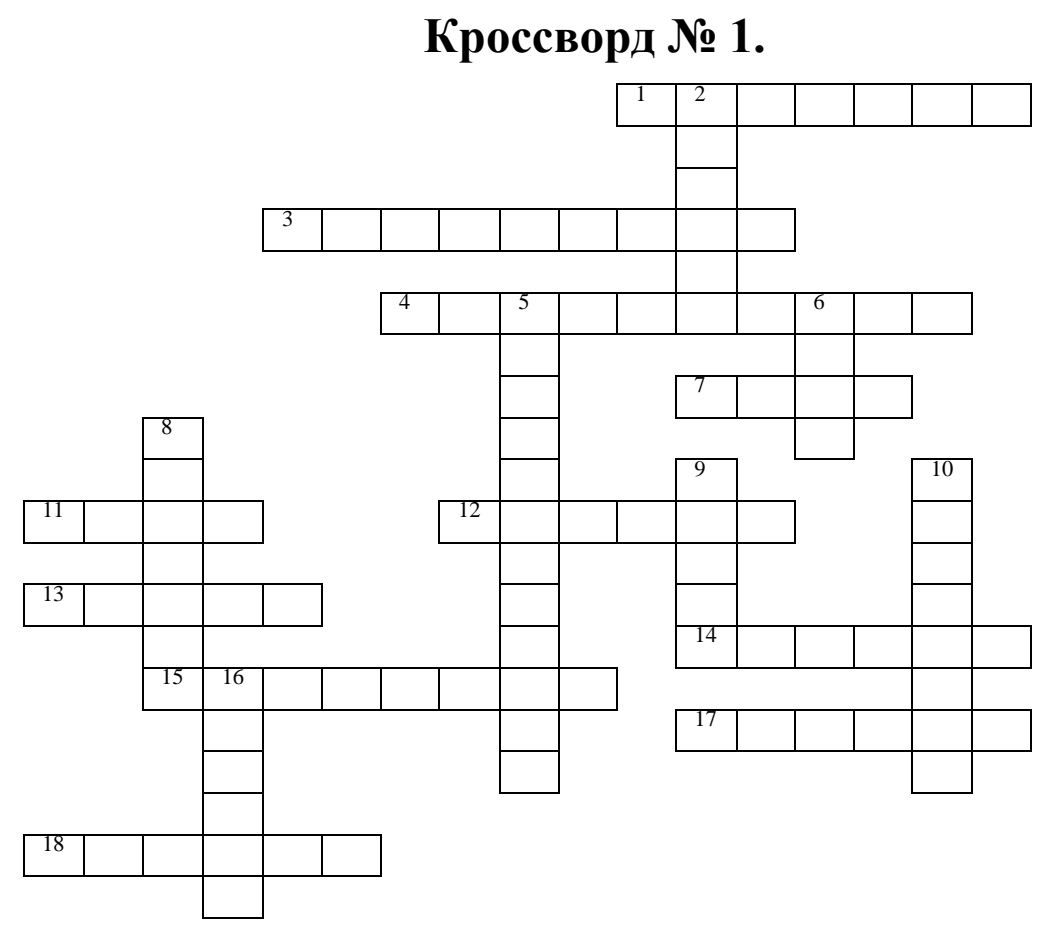

По горизонтали: 1. Нарицательная стоимость, обозначенная на ценных бумагах. 3. Ценная бумага, по которой ее владельцу выплачивается доход (за год или иной период времени) в форме процентов или выигрышей. 4. Текущая .... ценной бумаги на любой момент времени - это сумма процентных или дивидендных платежей за год, деленная на ее рыночную цену. 7. Опцион на покупку. 11. Рыночная цена акции в расчете на 100 денежных единиц номинала. 12. Цена, уплачиваемая одной из сторон опционного контракта. 13. Вексельное поручительство. 14. Список владельцев именных ценных бумаг на определенную дату. 15. Доход, выплачиваемый владельцу акции из чистой прибыли АО. 17. Добавочный лист к векселю. 18. Профессиональный участник рынка ценных бумаг, который торгует по поручению клиентов за комиссионное вознаграждение.

По вертикали: 2. Сделка, при которой один из участников имеет право отказаться от выполнения своих обязательств, уплатив другому определенную премию. 5. Операция, которая предназначена снизить риск, возникший в результате других операций. 6. Простой вексель. 8. Срочный контракт, все условия которого оговариваются сторонами при его заключении. 9. Профессиональный участник рынка ценных бумаг, совершающий сделки от своего имени, за свой счет и в своих интересах. 10. Лицо, на имя которого выписан переводный вексель. 16. Индикатор 
состояния рынка ценных бумаг, рассчитанный определенным образом на основе корзины наиболее ликвидных обыкновенных акций или облигаций. 


\section{Кроссворд № 2.}

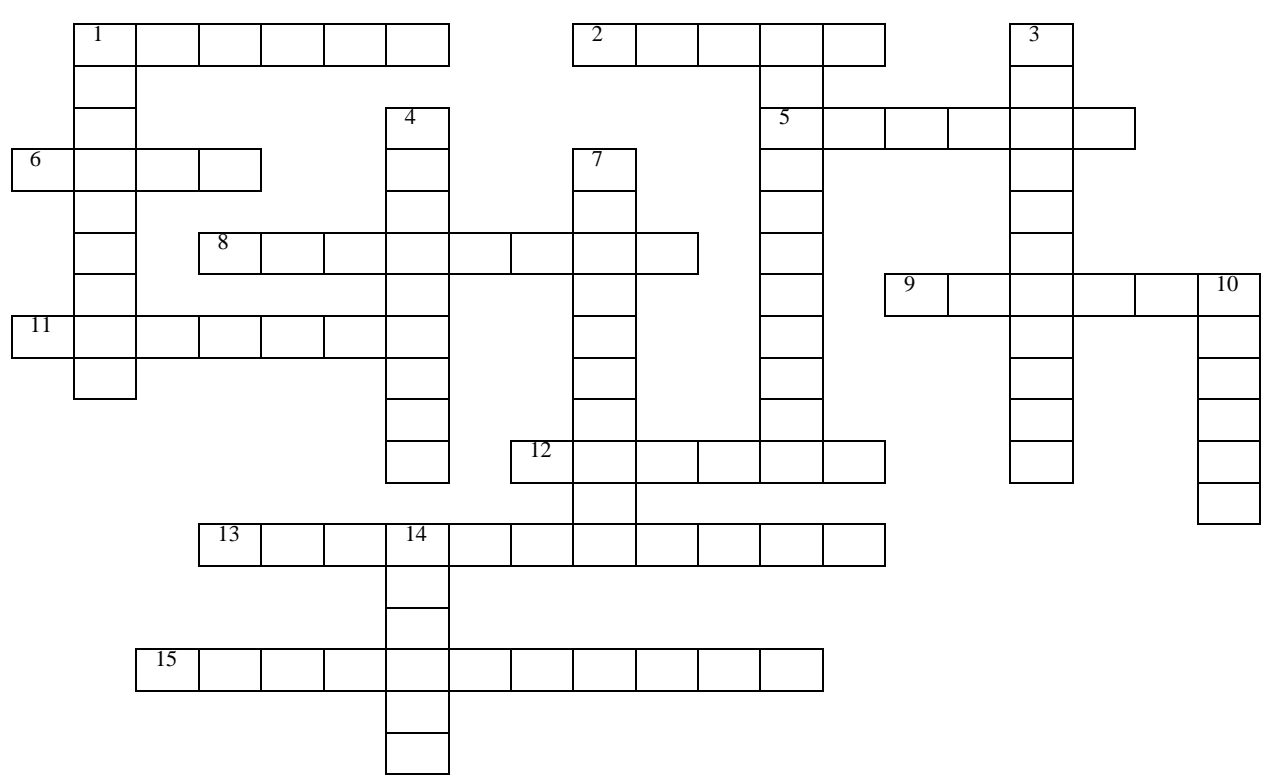

По горизонтали: 1. Ценная бумага - это ... рынка ценных бумаг. 2. Долевая ценная бумага. 5. Предмет вексельного обязательства. 6. Одно из качеств ценной бумаги. 8. Доход, получаемый акционером. 9. Авалист по векселю. 11. Величина, на которую номинальная стоимость облигации превышает цену ее продажи. 12. Общая база данных об акционерах. 13. Организация, которая хранит ценные бумаги по поручению клиентов и реализует, если имеет на это поручение клиента, их право по этим бумагам. 15. Качество ценной бумаги, проявляющееся в способности быть проданной быстро с минимальными денежными потерями.

По вертикали: 1. Долговое обязательство эмитента, выпустившего ценную бумагу, уплатить владельцу в оговоренный срок номинальную стоимость ценной бумаги и доход. 3. Участник рынка ценных бумаг, ведущий учет владельцев именных ценных бумаг по договору с эмитентом. 4. Процедура снятия ценной бумаги с торгов на бирже. 7. Ценная бумага, удостоверяющая заключение договора перевозки груза. 10. Переводной вексель. 14. Бывает пут или колл. 


\section{Кроссворд № 3.}

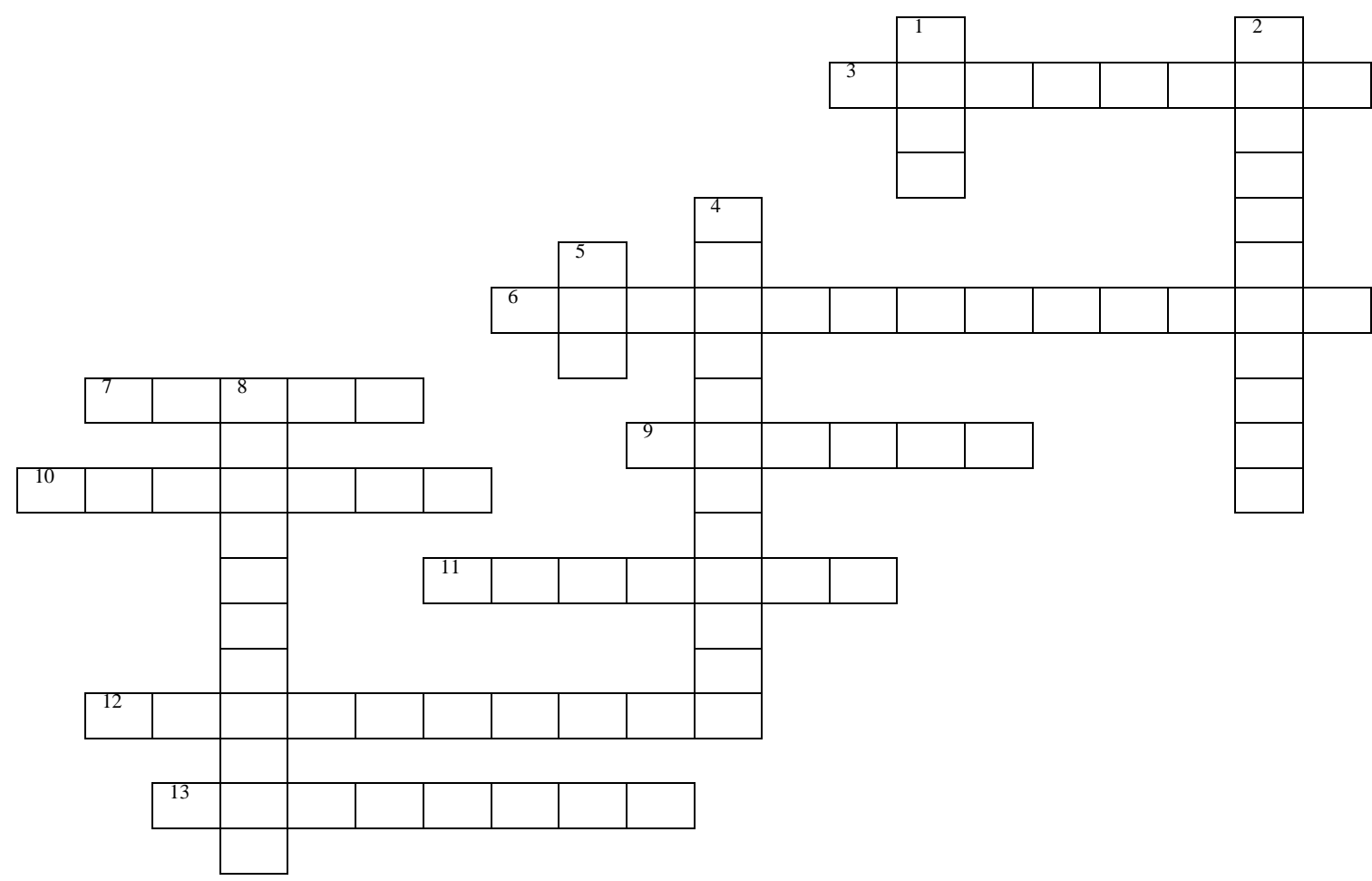

По горизонтали: 3. Доход акционера, выплачиваемый из чистой прибыли. 6. ... ценная бумага - ценная бумага, выпускаемая поштучно или небольшими сериями. 7. Участник рынка ценных бумаг, который самостоятельно торгует на свой страх и риск, используя собственные деньги. 9. Участник рынка ценных бумаг, который торгует по поручению клиентов за комиссионное вознаграждение. 10. Выраженная в процентах разница между номиналом векселя и суммой, уплачиваемой банком при его оплате до наступления срока платежа. 11. Выпуск в обращение денег и ценных бумаг. 12. Разновидность ценных бумаг в зависимости от формы доходов. 13. Разновидность ценных бумаг в зависимости от возможности досрочного погашения.

По вертикали: 1. Вероятность потерять вложенный капитал. 2. Передаточная надпись на оборотной стороне векселя. 4. ... ценные бумаги это ценные бумаги, которые обслуживают процесс товарооборота и определенные имущественные сделки. 5. Денежный документ, содержащий письменный приказ банку о выплате указанной в нем суммы денег. 8. Одно из качеств ценной бумаги. 


\section{Кроссворд № 4 .}

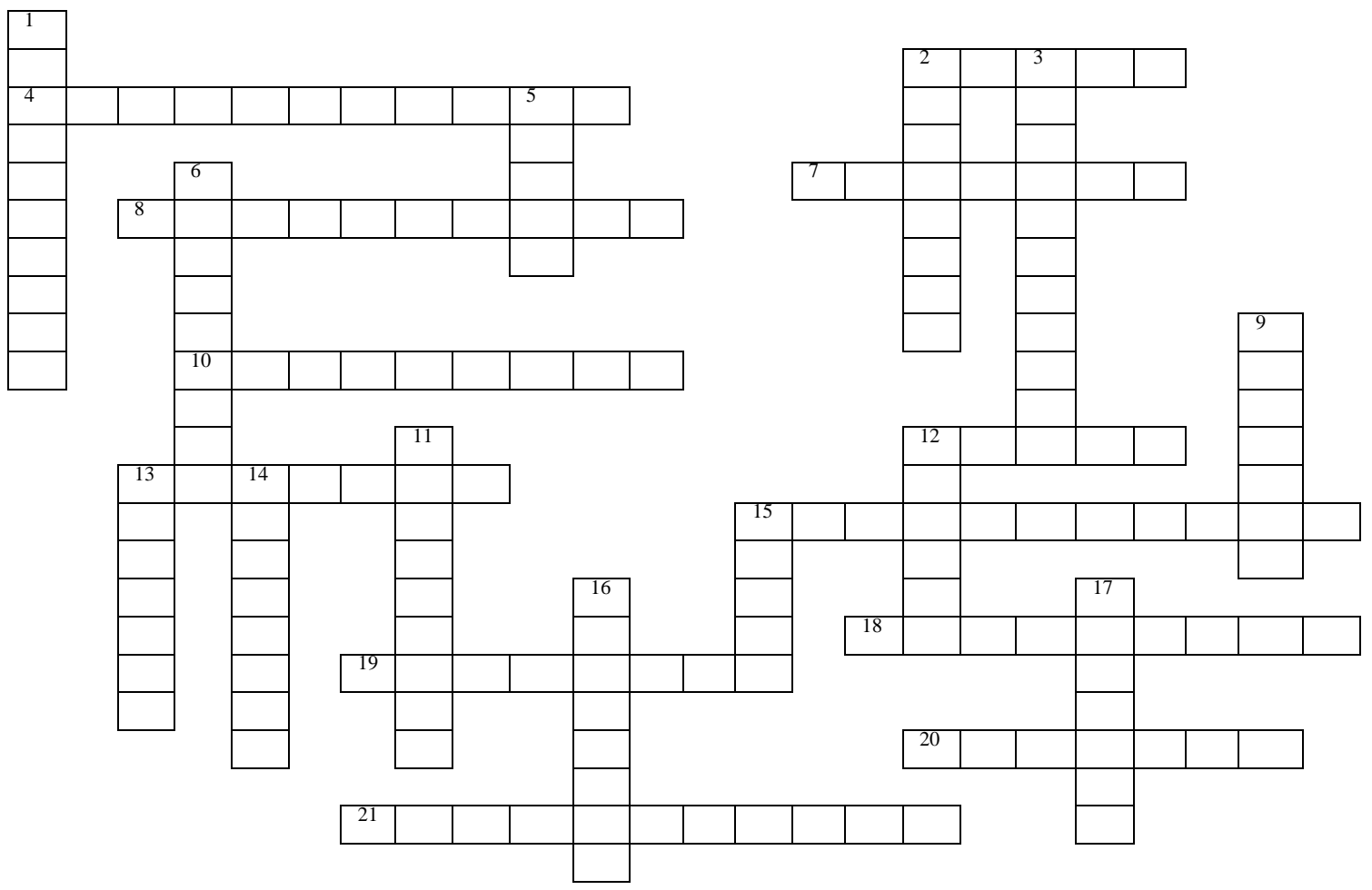

По горизонтали: 2. Гарантия, поручительство, согласно которому выдавшее ее лицо несет ответственность за оплату векселя перед его владельцем. 4. Организация, задачей которой является ведение списков (реестров) владельцев ценных бумаг. 7. Участник рынка, выдавший ценную бумагу в обмен на денежные средства или вещи (имущество), принадлежавшие инвестору, и несущий соответствующие обязательства по ценной бумаге перед инвестором. 8. Ценная бумага, удостоверяющая заключение договора перевозки груза. 10. Удостоверяет право ее владельца требовать погашения (выплату номинальной стоимости или номинальной стоимости и процентов) в установленные сроки. 12. Регулярно функционирующий, организационно определенный оптовый рынок однородных товаров, на котором заключаются сделки купли-продажи крупных партий товара. 13. Денежная сумма или вещь (имущество), владение или использование (употребление) которых их владельцем (собственником) приносит ему чистый доход в любой рыночной форме. 15. Организация, которая должна осуществлять хранение и/или учет ценных бумаг участников рынка. 18. Вознаграждение, получаемое брокером. 19. Владелец (собственник) ценной бумаги, ставший им в результате обмена на нее определенного количества принадлежавших ему денег или вещей 
(имущества). 20. Отчуждение ценной бумаги инвестором обратно эмитенту, сопровождающееся прекращением существования конкретной ценной бумаги. Обычно имеет место при окончании срока действия ценной бумаги. 21. Размещение одного вида ценной бумаги путем ее обмена на другой вид на заранее установленных условиях.

По вертикали: 1. Ценная бумага, удостоверяющая сумму вклада, внесенного в банк, и права вкладчика на получение по истечении установленного срока суммы вклада и обусловленных в ЦБ процентов в банке, выдавшем ЦБ, или в любом филиале этого банка. 2. Владелец акций, получающий прибыль по акциям в виде дивидендов 3. Размещение эмиссионных ценных бумаг в условиях развитого рынка осуществляется путем привлечения профессиональных участников фондового рынка, которые оказывают подобные услуги эмитентам. Такой участник рынка в других странах называется ... 5. Размещение акций акционерного общества, созданного в результате преобразования в него общества с ограниченной ответственностью или кооператива. 6. Доступная для всех участников рынка информация о рыночной цене ценной бумаги. 9. Установленная Федеральным законом «О рынке ценных бумаг» последовательность действий эмитента по размещению эмиссионных ценных бумаг. 11. Именная ценная бумага, которая удостоверяет права ее владельца в соответствии с договором об ипотеке на получение денежного обязательства или указанного в нем имущества. 12. Организации, которые заключают сделки по куплепродаже ценных бумаг для своих клиентов за счет самих клиентов. 13. Заключенная сделка проверяется на ее соответствие приказу клиента. 14. Размещение ценных бумаг путем заключения договора купли-продажи. 15. Организация, которая продает и покупает ценные бумаги от своего имени и за свой счет на основе объявленных ею цен. 16. Лицо, имеющее, благодаря своему служебному положению или родственным связям, доступ к конфиденциальной информации о делах фирмы. 17. Письменное обязательство должника без всяких условий уплатить держателю ценной бумаги обозначенную в ней денежную сумму и в установленный в ней срок. 


\section{Ответы к кроссвордам}

Oтветы к кроссворду № 1. По горизонтали.1. Номинал. 3. Облигация. 4. Доходность. 7. Колл. 11. Курс. 12. Премия. 13. Аваль. 14. Реестр. 15. Дивиденд. 17. Аллонж. 18. Брокер.

По вертикали. 2. Опцион. 5. Хеджирование. 6. Соло. 8. Форвард. 9. Дилер. 10. Ремитент. 16. Индекс.

Oтветы к кроссворду № 2. По горизонтали. 1 Объект. 2. Акция. 5. Деньги. 6. Риск. 8. Дивиденд. 9. Гарант. 11. Дисконт. 12. Реестр. 13. Депозитарий. 15. Ликвидность.

По вертикали. 1. Облигация. 3. Регистратор. 4. Делистинг. 7. Коносамент. 10. Тратта. 14. Опцион.

Oтветы к кроссворду № 3. По горизонтали. 3. Дивиденд. 6. Неэмиссионная. 7. Дилер. 9. Брокер. 10. Дисконт. 11. Эмиссия. 12. Процентные. 13. Отзывные.

По вертикали. 1. Риск. 2. Индоссамент. 4. Коммерческие. 5. Чек. 8. Ликвидность.

Oтветыл к кроссворду № 4. По горизонтали. 2. Аваль. 4. Регистратор. 7. Эмитент. 8. Коносамент. 10. Облигация. 12. Биржа. 13. Капитал. 15. Депозитарий. 18. Брокеридж. 19. Инвестор. 20. Гашение. 21. Конвертация. По вертикали. 1. Сертификат. 2. Акционер. 3. Андеррайтер. 5. Обмен. 6. Котировка. 9. Эмиссия. 11. Закладная. 12. Брокер. 13. Клиринг. 14. Подписка. 15. Дилер. 16. Инсайдер. 17. Вексель. 


\section{Глоссарий}

A

Аваль - письменное финансовое поручительство, форма гарантии банка или фирмы, способствующая повышению доверия к финансовым возможностям владельца оборотного кредитно-денежного документа.

Агрессивный инвестор - инвестор, который реализует цели получения максимально высокой курсовой разницы от каждой сделки при высоком уровне риска и ограниченном длительностью инвестиционной операции сроке инвестирования

Акция - ценная бумага, удостоверяющая участие ее владельца в капитале акционерного общества и дающая ему право на получение дохода в виде дивиденда.

Ажсио - отклонение рыночного курса ценных бумаг от их номинала в сторону повышения. Определяется в процентах к номиналу. Противоположностью ажио является дизажио, т.е. отклонение курса в сторону уменьшения.

Аккредитив - документ, эмитированный коммерческим банком и свидетельствующий, что последний принимает на себя обязательство об оплате векселей. Лицо, от имени которого банк выписывает аккредитив, называется аппликантом, или заявителем.

Активы - материальные, денежные средства и ценные бумаги компании. К активам относится и репутация компании. Дебиторская задолженность (долговые обязательства сторонних организаций) компании также является частью ее активов.

Акцептант - лицо, подписывающее вексель (тратту) и берущее этим на себя обязательство уплатить по нему при наступлении срока платежа. 
Акционер - владелец обыкновенных или привилегированных акций, наделенный соответствующими правами относительно компании эмитента этих акций.

Акциионерное общество - организационно-правовая форма предприятия, которое по своим обязательствам отвечает только тем имуществом, которое ему принадлежит. В таком обществе ведется реестр акционеров, являющихся совладельцами общества.

Акциионерныц̆ капитал - капитал компании образовавшийся путем эмиссии обыкновенных и привилегированных акций

Акиия - ценная бумага, дающая своему владельцу праве получения дивидендов, а также право голоса на собрании акционеров.

Акичия бесплатная - ценная бумага, распределяемая среди акционеров на бесплатной основе, как правило, пропорционально количеству ранее полученных обыкновенных акций.

Акциия грошовая - ненадежная, низко оцениваемая ценная бумага, котирующаяся на внебиржевом рынке.

Акичя именная - ценная бумага, имя владельца которой, во-первых, указано в ней и, во-вторых, занесено в реестр акционеров.

Акичя кумулятивная привилегированная - вид привилегированной акции, владельцы которой могут получить дивиденды, накопленные за ряд лет, в течение которых корпорация их не выплачивала. При этом дивиденды будут выплачены до получения дивидендов держателями обыкновенных акций. Привилегированные акции, неполученные дивиденды по которым теряются навсегда называются некумулятивными привилегированными акциями.

Акция обыкновенная - в сумме такие акции составляют большую часть акционерного капитала общества. Их владельцы имеют право на получение дивидендов, на участие в общих собраниях и в управлении обществом. При ликвидации акционерного общества они вправе получить вложенные 
средства по номинальной цене, но только после удовлетворения интересов держателей облигаций и привилегированных акций.

Акичя ограниченная - акция, приносящая обычные дивиденды, но не дающая права голоса или ограничивающая возможность воспользоваться этим правом.

Акиия привилегированная - акция, предоставляющая ее владельцу привилегированное право на получение дивидендов, но не дающая ему права голоса на собрании акционеров (в случае если иное не предусмотрено в уставе компании).

Акциия на предъявителя - акция без указания имени владельца. Права акционера может осуществлять любой ее предъявитель. К числу предъявительских акций могут быть отнесены только полностью оплаченные акции.

Акциия роста - обыкновенная акция быстро растущих компаний, действующих в ведущих отраслях. Обеспечивает быстрое увеличение объема инвестированного капитала, но обычно приносит малый дивиденд.

Акиия учредительская - акция, распространяемая среди учредителей акционерных компаний и дающая им некоторые преимущественные права. Держатели таких акций могут: иметь дополнительное количество голосов на собрании акционеров; пользоваться первоочередным правом на получение акций в случае их последующих эмиссий; играть главную роль в решении всех вопросов, связанных с деятельностью акционерных компаний.

Акичий контрольный пакет - для контроля за деятельностью компании необходимо владеть 51\% эмитированных голосующих акций. На практике для осуществления такого контроля можно иметь и меньший пакет акций, так как в больших акционерных обществах владение акциями “распылено” между отдельными лицами. 
Аллонж - прикрепляемый к векселю дополнительный лист, на котором ставится поручительская гарантия.

Андеррайтер - гарант размещения выпуска ценных бумаг компаний. Комплекс мер, осуществляемых андеррайтером, называется андеррайтингом. Аттестация ФСФР - это обучающие программы, созданные Федеральной службой по финансовым рынкам (ФСФР). Данные программы в первую очередь, ориентированы на специалистов рынка ценных бумаг. Аттестация ФСФР представляет собой профессиональную подготовку всех желающий для работы на финансовом рынке;

Aудит - проверка финансовой отчетности компании на достоверность содержащейся в ней информации, а также на соответствие ее нормам и требованиям действующего законодательства.

Аукиион - метод проведения торговли каким-либо товаром, ценными бумагами. Различают: английский аукцион (повышающий), голландский (понижающий), двойной, закрытый тендер.

\section{Б}

Балансовая стоимость акичй - стоимость активов компании, приходящихся на одну обыкновенную акцию в соответствии с данными финансовой отчетности. Как правило, данная стоимость слабо связана с курсом ценных бумаг.

Безрисковый актив - актив, будущие потоки по которому известны заранее. Как правило — государственные ценные бумаги.

Биржа - организационная форма оптовой, в том числе международной, торговли массовыми товарами, имеющими устойчивые и четкие качественные параметры (товарная биржа), или систематических операций по купле-продаже ценных бумаг, золота, валюты (фондовая биржа). Биржа фондовая - организационно оформленный, регулярно функционирующий 
рынок по купле-продаже ценных бумаг, при помощи которого в условиях промышленного развития стран осуществляется основная масса долгосрочных вложений капитала.

Биржевая сессия - установленное законодательством или общепринятыми правилами время проведения торгов в зале фондовой биржи.

Брокер - финансовый посредник, занимающийся куплей продажей ценных бумаг за счет и по поручению клиента на основании договора комиссии или поручения. Посреднические операции называются брокеражем, за выполнение их брокер взимает комиссии.

Брокер зарегистрированный - участник фондовой биржи, торгующий ценными бумагами за свой счет и (или) за счет своей фирмы и обязанный при поступлении соответствующего требования от руководства биржи исполнить определенные действия с целью изменения курса ценных бумаг.

Бык - участник рынка ценных бумаг, принимающий определенные меры для повышения курса ценных бумаг. Для этих целей он вначале покупает ценную бумагу по более низкой цене, а впоследствии продает ее по более высокой. Бэк-офис - подразделение брокерской компании, обеспечивающее исполнение сделок после их заключения и осуществляющее внутренний учет и контроль операций с ценными бумагами.

B

Варрант - свидетельство, выдаваемое вместе с ценной бумагой и дающее право на дополнительные льготы ее владельцу по истечении определенного срока.

Вексель - ценная бумага, дающая ее владельцу право на получение указанной суммы денег в установленный срок. Выпускается в обращение и принимается к платежу с учетом процентной ставки и срока действия 
Вексель дисконт - продажа или перевод векселе по стоимости ниже номинала.

Вексель долгосрочный - переводной вексель, срок погашения которого составляет не менее тридцати дней с даты предъявления. На практике, однако, этот термин используется применительно к векселям со сроками оплаты 60-90 дней.

Вексель переводной - письменное долговое обязательство на определенную сумму денег в той или иной валюте предусматривающее конкретный срок платежа. В случае если к такому векселю не прикладываются сопроводительные документы (транспортная накладная, коносамент и др.), он называется чистым векселем. Вексель переводной, используемый как расчетный документ при продаже или покупке конкретных товаров за границей, называется.

Вексель предъявительский - вексель, подлежащий оплате по первому требованию кредитора.

Внебиржевой рынок - децентрализованный рынок, на котором дилеры покупают и продают финансовые активы и инструменты.

Волатильность - статистический показатель, характеризующий изменение цены или доходности финансового актива (инструмента) во времени.

Вторичныци рынок - рынок, на котором происходит послеэмиссионное обращение финансовых активов и инструментов.

Bысокодоходные облигац̧ии - облигации, имеющие низкий кредитный рейтинг (ниже тройного ВВВ). Называются иногда еще мусорными облигациями. 


\section{$\Gamma$}

Гарант - поручитель. Государство, учреждение или лицо, дающее в чем-либо гарантию, в том числе гарантирующее выплату фиксированного дивиденда по привилегированным акциям или процентов по облигациям.

Государственные ценные бумаги - облигации, казначейские векселя и другие государственные обязательства, выпускаемые центральным правительством с целью размещения займов и мобилизации денежных ресурсов.

\section{Д}

Дата погашения - срок, по наступлении которого необходимо произвести погашение облигаций и (или) возвращение долгов.

Дата регистрации - дата, до наступления которой владелец акции должен быть зарегистрирован в реестре акционеров в качестве акционера компании для получения объявленного дивиденда и права голосовать на собрании акционеров.

Дебетовый баланс - на маржевом счете покупателя та часть товаров или ценных бумаг, которая была приобретена за счет выданного покупателю кредита брокера.

Делистинг - отзыв ценных бумаг с фондовой биржи в случае обесценения акций, перемен, происходящих в компании-эмитенте.

Депозитарий - централизованное хранилище ценных бумаг различных видов, позволяющее осуществлять торговлю ими без их физического перемещения, с помощью компьютерных систем и сертификатов.

Депозитный сертификат - свидетельство банка-эмитента о вкладе денежных средств, удостоверяющее право вкладчика или его правопреемника на получение по истечении установленного срока суммы депозита и процентов по нему. 
Дивиденд - часть чистой прибыли акционерного общества, распределяемая среди акционеров пропорционально числу акций, находящихся в их собственности. Общий размер дивиденда определяется после вычета из полученной прибыли налогов, отчислений в фонд расширения производства, пополнении страховых резервов, выплаты процентов по облигациям и др. Размер фиксированного дивиденда по привилегированным акциям устанавливается при их выпуске.

Дивиденд дополнительный - дивиденд в виде ценных бумаг или наличных денег, выплачиваемый компанией в добавление к обычному дивиденду.

Дивидендное покрытие - число, показывающее, во сколько раз прибыль компании превышает сумму выплачиваемых дивидендов.

Диверсификация - распределение инвестиций между различными типами ценных бумаг и компаниями, относящимися к нескольким отраслям производства.

Дилер - участник рынка ценных бумаг, торгующий ценными бумагами и за свой счет, и по поручению.

Дисконт - разница между ценой финансового инструмента, соответствующей его номиналу, и реально уплаченной за него ценой, меньшей номинала.

Дисконтная (учетная) ставка - процентная ставка, которую центральный банк взимает при учете правительственных ценных бумаг или при предоставлении кредита против обеспечения в виде этих бумаг.

Доверительные операции банков - операции банков по управлению имуществом и выполнению новых услуг в интересах и по поручению клиента на правах доверительного лица.

Для частных лиц они выполняют функции депозитария и консультанта (хранение ценных бумаг, консультации и рекомендации по вопросам покупки и продажи ценных бумаг и т.д.), управления имуществом по доверенности и т.п. Для фирм доверительные операции банков включают: 
обслуживание облигационных займов, сопровождающихся передачей банку права распоряжения имуществом; выполнение функций агента для акционерных компаний и т.д.

Доходность - один из основных показателей качества ценных бумаг. Представляет собой отношение выплачиваемых дивидендов к стоимости ценной бумаги; выражается в процентах.

$\mathbf{E}$

Еврооблигация - вид международных ценных бумаг; выражает отношение займа между ее предъявителем и эмитентом. Эмитентами и андеррайтерами таких ценных бумаг выступают эмиссионные синдикаты, состоящие из банков, находящихся в главных европейских странах.

\section{3}

Задержка открытия - задержка начала биржевой сессии сверх обычного времени ее открытия из-за каких-либо рыночных условий, потребовавших от руководства биржи провести данное вмешательство.

Заказ на покупку (продажу) ценных бумаг - указание на совершение сделки на срок по наиболее благоприятной достижимой цене на момент выхода на рынок.

Закладная - требование в отношении определенного имущества, предоставляемого заемщиком в качестве обеспечения кредита, реализуемое кредитором в случае, если заемщик оказывается не в состоянии совершить платежи, оговариваемые в кредитном контракте. Облигации, обеспеченные таким образом, называются закладными. 


\section{И}

Инвестиционный банк - гарантирует эмитенту размещение ценных бумаг среди инвесторов и размещает их.

Инвестищионная компания - разновидность кредитно-финансовых институтов, аккумулирующих денежные средства инвесторов путем эмиссии собственных ценных бумаг (обязательств). Размещает эти средства в акции и облигации различных эмитентов как в своей стране, так и за рубежом.

Инвестищионный фонд - любое акционерное общество открытого типа, деятельность которого заключается в привлечении средств за счет эмиссии акций, а также в инвестировании этих средств в ценные бумаги других эмитентов. Различают следующие категории инвестиционных фондов: 1) инвестиционные фонды, рассчитанные на получение инвестором высоких постоянных дивидендов;

2) инвестиционные фонды, ориентированные на приращение капитала инвестора

3) инвестиционные фонды, рассчитанные на надежное размещения средств инвестора.

Инвестор - субъект инвестиционной деятельности, осуществляющий вложение собственных или заемных средств в форме инвестиций и обеспечивающий их целевое использование. Различают инвесторов институциональных и индивидуальных.

Индексы биржевые - средние или средневзвешенные показатели курсов ценных бумаг, как правило, акций, обычно применяются для оценки изменений курсов какого-либо репрезентативного набора ценных бумаг.

Индекс Доу-Джснса (Dow Jones average) - средний показатель изменения курсов акций группы крупнейших компаний США. Имеется несколько видов данного индекса, а именно: составной индекс Доу-Джонса (Dow Jones comprosite), являющийся сводным индексом из всех отраслевых; 
промышленный индекс Доу-Джонса (Dow Jones industrial average) показатель изменения курсов акций 30 крупнейших промышленных компаний; транспортный индекс Доу-Джонса (Dow-Jones transportation average) - показатель изменения курсов акций 20 транспортных корпораций; коммунальный индекс Доу-Джонса (Dow Jones municipal average) - показатель движения курсов акций 15 компаний газо- и электроснабжения.

Индекс Доу-Джсонса. Теория Доу - теория анализа рынка ценных бумаг, основанная на изучении показателей промышленного и транспортного индексов Доу-Джонса. Еe основное положение гласит, что при возникновении новой тенденции значения обоих индексов должны изменяться в одном и том же направлении; в противном случае, т. е. если устойчиво изменяется в одном направлении лишь один из индексов, рыночный сигнал считается ложным.

Индекс Нью-Йоркской фондовой биржи - взвешенный по рыночной стоимости показатель движения курсов акций всех корпораций, зарегистрировавших свои ценные бумаги на этой бирже.

Индекс Уилшир 5000 (Wilshire 5000) - самый репрезентативный из публикуемых индекс американских фондовых рынков. Он является взвешенным по рыночной стоимости всех акций, входящих в его состав, и отражает стоимость акций всех корпораций, котируемых на Нью-Йоркской фондовой бирже и во внебиржевом обороте, - около 5 тыс. выпусков различных акций.

Индоссамент - передаточная подпись (с сопроводительной надписью или без нее) на оборотной стороне документа. Совершающий индоссамент индоссант - гарантирует тем самым выполнение в срок определенных операций по данному документу. Индоссирование расчетного документа 
представляет собой акт переуступки - права собственности на документ и покрываемые им товарно-материальные ценности или денежные средства.

\section{$\mathbf{K}$}

Казначейская эмиссия - осуществляемая казначейством или другими государственными органами эмиссия ценных бумаг; обычно ее основная цель - покрытие бюджетного дефицита.

Казначейские векселя - вид краткосрочных обязательств государства. Выпускаются сроком на 3, 6 и 12 месяцев, обычно на предъявителя. Не имеют процентных купонов. Реализуются преимущественно среди банков со скидкой от номинала, а выкупаются по полной нарицательной стоимости. Эмиссия и погашение казначейских векселей производятся регулярно центральными банками по поручению казначейств.

Капитал акц̧ионерного общеества - совокупность индивидуальных капиталов, объединенных посредством выпуска и размещения акций и облигаций. Средства от выпуска и размещения акций образуют собственный капитал акционерного общества который может в дальнейшем увеличиваться за счет капитализация части прибыли и путем дополнительной эмиссии акций. Средства, полученные от размещения облигаций, составляют заемный капитал акционерного общества; эти средства через определенное время должны быть возвращены владельцам облигаций вместе с процентными суммами. Различают: собственный капитал, заемный капитал, оплаченный капитал.

Капитализация - общее количество ценных бумаг разных видов, выпущенное корпорацией.

Капитализащчи доходов - обращение полученных акционерами доходов на развитие предприятия. 
Кассовая сделка - 1) один из видов операций с ценными бумагами, совершаемых на фондовых биржах Особенность кассовой сделки заключается в том, что ценные бумаги оплачиваются и передаются покупателю, как правило, в день заключения сделки (максимально - до семи дней). В форме кассовой сделки совершаются обычно операции с мелкими партиями ценных бумаг; 2) разновидность валютных операций на валютном рынке.

Качество ценной бумаги - проявляется в следующих характеристиках: ликвидность ЦБ, доходность ценной бумаги, риск ЦБ

Клиринг - система безналичных расчетов за товары ценные бумаги и услуги, основанных на зачете взаимных требований и обязательств.

Колл-опцุион (опцион на покупку) - опцион, который дает право купить актив. Комитент - сторона в договоре комиссии, поручающая другой стороне (комиссионеру) совершать за вознаграждение - комиссию - одну или несколько сделок с товарами, векселями, акциями облигациями и т.д. Сделки заключаются от имени комиссионера, но в интересах и за счет комитента.

Конверсия - обмен акций или облигаций одного типа на ценные бумаги другого типа, но эмитированные одной и той же компанией. В проспекте о выпуске облигаций и привилегированных акций часто предусматривают право конверсии, которое позволяет держателям этих ценных бумаг обменивать их на другие бумаги, обычно простые акции, по определенному курсу (или цене) конверсии.

Конечная (полная) доходность изенной бумаги - характеризует полный доход по ценной бумаге, приходящийся на единицу затрат на ее покупку в расчете на год.

Коносамент - документ стандартной формы, принятой в международной практике, на перевозку груза, который удостоверяет его погрузку, перевозку и право на получение. 
Консервативный инвестор - инвестор, целью которого является получение стабильного дохода в течение длительного времени

Контрольный пакет акций - количество акций, дающее право инвестору осуществлять контроль над деятельностью фирмы

Курс иенных бумаг - рыночная цена, по которой осуществляются покупка и продажа ценных бумаг в определенный момент времени

\section{$\mathbf{H}$}

Недобросовестная эмиссия - действия, выражающиеся в нарушении процедуры эмиссии и являющиеся основанием для отказа в регистрации выпуска ценных бумаг, признания его несостоявшимся или приостановления эмиссии ценных бумаг.

Номинальная стоимость облигащчии - обозначенная цена облигации, по которой осуществляется ее погашение

\section{$\mathbf{O}$}

Облигаџия - ценная бумага, представляющая собой долговое обязательство эмитента через определенный срок возместить владельцу вложенных средств номинальную стоимость облигации и уплатить по ней фиксированный процент

Обратимость акичии - предполагает наличие у владельца акции возможности в любой момент реализовать ее, т.е. превратить в деньги.

Обращуение изенных бумаг - переход права собственности от одного их держателя (владельца) к другому при заключении ими гражданско-правовых сделок.

Опцุион - право покупки акции компании по заданной цене (цене исполнения) в определенный временной промежуток или момент времени. 


\section{П}

Переводной вексель (тратта) - письменный документ, содержащий безусловный приказ векселедателя плательщику уплатить определенную сумму денег в установленный срок и в конкретном месте векселедержателю или его приказу. Плательщик и векселедатель - разные лица.

Портфель иенных бумаг - инвестиционный портфель, состоящий из приобретенных ценных бумаг

Программы $A D R$ u GDR - способы привлечения прямых зарубежных инвестиций эффективно работающими российскими предприятиями, которые связаны с выпуском и размещением среди потенциальных стратегических инвесторов глобальных депозитарных расписок (GDR) и американских депозитарных расписок (ADR) на акции российского эмитента Потребительная стоимость акиии - ее способность приносить доход в виде дивиденда и в результате роста курсовой стоимости.

Простой вексель (соло) - письменный документ, содержащий простое и ничем не обусловленное обязательство векселедателя (должника) уплатить определенную сумму денег в установленный срок и в конкретном месте векселедержателю или его приказу.

Пут-опциион (опцион на продажу) - опцион, который дает право продать актив.

\section{$\mathbf{P}$}

Расчетно-клиринговая организащия (РКО) - профессиональный участник рынка ценных бумаг, специализированная организация, которая осуществляет расчетное обслуживание участников организованного рынка ценных бумаг и выявляет их позиции по результатам заключенных сделок. Регулирование рынка цеенных бумаг - упорядочение деятельности на нем всех его участников и операций между ними 
Реестр - список владельцев именных ценных бумаг, составленный на определенную дату

Региональные цеенные бумаги - способ привлечения финансовых ресурсов региональными органами государственной власти в случае дефицита регионального бюджета или на инвестиционные цели путем выпуска долговых ценных бумаг.

Регистратор - организация, которая по договору с эмитентом ведет реестр. Рынок ценных бумаг (фондовый рынок) - сегмент финансового рынка, где объектом купли-продажи являются ценные бумаги (фондовые инструменты) Рыночная стоимость имущуества - цена, по которой продавец, имеющий полную информацию о стоимости имущества и не обязанный его продавать, согласен был бы продать его, а покупатель, имеющий полную информацию о стоимости имущества и не обязанный его приобрести, согласен был бы приобрести.

\section{C}

Сберегательный сертификат - ценная бумага, удостоверяющая сумму вклада, внесенного в банк гражданином, и его права на получение в этом банке или в его филиалах по истечении установленного срока суммы вклада и причитающихся по нему процентов.

Cвоп - договор обмена базовыми активами и (или) платежами на их основе в течение установленного периода, в котором цена одного из активов является твердой (фиксированной), а цена другого - переменной (плавающей), или же обе эти цены являются переменными.

Сделка с премией - сделка, при которой сторона - плательщик премии получает право отступного, т.е. за уплату ранее установленной суммы отказывается от выполнения контракта в случае его невыгодности или теряет определенную сумму в случае исполнения контракта. 
Складское свидетельство - это ценная бумага, удостоверяющая принятие товара на хранение по договору складского хранения.

Стратегический инвестор - инвестор, деятельность которого направлена на захват сферы влияния и установление контроля над собственностью путем приобретения паритетного пакета акций

\section{$\mathbf{T}$}

Текущุая доходность изенной бумаги - годовые (текущие) поступления по ценной бумаге относительно произведенных затрат на ее покупку.

Технический анализ - совокупность методов анализа динамики котировок отдельных ценных бумаг и всего рынка в целом на основе постоянно изменяющегося спроса и предложения.

Твердые сделки - сделки на срочном рынке ценных бумаг, обязательные для исполнения.

\section{$\mathbf{y}$}

Умеренный инвестор - инвестор, ориентирующийся на уровень дохода, который может формироваться как за счет дивидендных и процентных выплат, так и за счет курсовой разницы при рассчитанном уровне риска Условные сделки - предоставляют одному из контрагентов право исполнить или не исполнить заключенный контракт.

Участники рынка ценных бумаг - физические лица или организации, которые продают либо покупают ЦБ, обслуживают их оборот и расчеты по ниМ. 


\section{$\Phi$}

Финансовыци рынок - рынок, где объектом купли-продажи являются финансовые активы. Основные сегменты финансового рынка - рынок кредитных ресурсов и рынок ценных бумаг

Фондовая биржа - институционально организованный рынок ценных бумаг, функционирующий на основе централизованных предложений о куплепродаже ценных бумаг, выставляемых биржевыми брокерами по поручениям институциональных и индивидуальных инвесторов

Фондовыцй индекс - индикатор конъюнктуры фондового рынка, средний показатель динамики курсовой стоимости акций ведущих компаний. К наиболее известным фондовым индексам относятся: в США - индексы Доу Джонса и "Стандарт энд Пурз", в Японии - индекс "Никкей", в Великобритании - индексы "футси"

Форвардный контракт - внебиржевая срочная сделка о купле-продаже в будущем товара с исполнением в заранее оговоренный срок.

Фронт-офис - торговые подразделения брокерской компании, сотрудники которого заключают сделки с ценными бумагами по поручению клиентов; Фундаментальный анализ - исследование корпорации-эмитента, состояния экономики в целом и экономики отрасли, в которой действует корпорация с точки зрения их влияния на изменение курса ценной бумаги.

Фьючерсный контракт - стандартный биржевой договор купли-продажи (поставки) биржевого актива через определенный срок в будущем по цене, установленной сторонами сделки в момент ее заключения.

\section{$\mathbf{X}$}

Хеджирование - способ страхования рисков 


\section{Ц}

Ценная бумага - это форма существования капитала, отличная от его товарной, производительной и денежной форм, которая может передаваться вместо него самого, обращаться на рынке как товар и приносить доход.

\section{$\mathbf{Y}$}

Чек - это ценная бумага, содержащая ничем не обусловленное распоряжение чекодателя банку произвести платеж указанной в нем суммы чекодателю.

\section{Э}

Эмиссия - выпуск в обращение денежных знаков, платежных средств, ценных бумаг, в результате которого возрастает денежная масса

Эмиссионная стоимость акции - стоимость размещения акций на первичном рынке.

Эмиссионный доход (выручка) - превышение эмиссионной стоимости над номинальной стоимостью

Эмитент - юридическое лицо, группа юридических лиц, связанных между собой договором, или органы государственной власти и местного самоуправления, несущие от своего имени обязательства перед инвесторами по осуществлению прав, удостоверенных ЦБ. 


\section{Литература}

1. Аскинадзи, В.М. Рынок ценных бумаг: учеб. пособие / В.М. Аскинадзи. - М.: Маркет ДС, 2009. - 128 с.

2. Базовый курс по рынку ценных бумаг. - М.: КноРус, 2010. - 448 с.

3. Баранов, Э.А., Рынки: валютные и ценных бумаг / Э.А. Баранов, О.В. Хмыз. - М.: Экзамен, 2001.

4. Бердникова, Т.Б. Рынок ценных бумаг и биржевое дело: учеб. пособие / Т.Б. Бердникова. - М.: Инфра-М, 2004. - 270 с.

5. Булатов, В.В. Фондовый рынок в структурной перестройке экономики / В.В. Булатов. - М.: Наука, 2002. - 416 с.

6. Буренин, А.Н. Рынок ценных бумаг и производных финансовых инструментов / А.Н. Буренин. - М.: Изд-во НТО, 2011. - 394 с.

7. Буренин, А.Н. Форварды, фьючерсы, опционы, экзотические и погодные производные / А.Н. Буренин. - М.: Изд-во НТО, 2011. - 466 с.

8. Галанов, В.А. Производные инструменты срочного рынка: фьючерсы, опционы, свопы: учебник / В.А. Галанов. - М.: Финансы и статистика, 2002. $-464 \mathrm{c}$.

9. Дегтярева, О.И. Биржевое дело / О.И. Дегтярева. - М.: Магистр, 2007. $624 \mathrm{c}$.

10.Едронова, В.Н. Рынок ценных бумаг / В.Н. Едронова, Т.Н. Новожилова. - М.: Магистр, Инфра-М, 2010. - 208 с.

11.Килячков, А.А. Практикум по российскому рынку ценных бумаг / А.А. Килячков, Л.А. Чалдаева. - М.: БЕК, 2001. - 552 с.

12.Килячков, А.А. Рынок ценных бумаг: курс в схемах / А.А. Килячков. М.: Юристъ, 2003. - 392 с. 
13.Коган, Е.Б. Я понимаю своего брокера. Краткий словарь терминов и определений / Е.Б. Коган, Е.В. Назаренкова, А.В. Паранич; под общ. ред. Е.В. Назаренковой. - М.: И-трейд, 2006. - 48 с.

14.Колб, Р.У. Финансовые деривативы: учебник: пер. с англ. / Р.У. Колб. М.: Филинъ, 1997. - 360 с.

15.Колесников, В.И. Практикум по курсу «Ценные бумаги» / В.И. Колесников, В.С. Торкановский. - М.: Финансы и статистика, 2001. $304 \mathrm{c}$.

16.Колтынюк, Б.А. Ценные бумаги / Б.А. Колтынюк. - СПб.: Изд-во Михайлова В.А., 2004. - 336 с.

17.Краев, А.О. Рынок долговых ценных бумаг / А.О. Краев, И.Н. Коньков, П.Ю. Малеев. - М.: Экзамен, 2002. - 512 с.

18.Лялин, В.А. Ценные бумаги / В.А. Лялин, П.В. Воробьёв. - М.: Проспект: ТК Велби, 2008. - 384 с.

19.Маренков, Н.Л. Ценные бумаги / Н.Л. Маренков. - М.: Феникс, 2005. $608 \mathrm{c}$.

20.Матросов, С.В. Европейский фондовый рынок / С.В. Матросов. - М.: Экзамен, 2002. - 256 с.

21.Мещерова, Н.В. Организованные рынки ценных бумаг / Н.В. Мещерова. - М.: Логос, 2000. - 200 c.

22. Миркин, Я.М. Рынок ценных бумаг России. Воздействие фундаментальных факторов, прогноз и политика развития / Я.М. Миркин. - М.: Альпина Паблишер, 2002. - 624 с.

23.Найман, Э.Д. Малая энциклопедия трейдера / Э.Д. Найман. - М.: Альпина Паблишер, 2009. - 456 с.

24.Просветов, Г.И. Ценные бумаги: задачи и решения: учеб.-практ. пособие / Г.И. Просветов. - М.: Альфа-Пресс, 2008. - 224 с. 
25.Резго, Г.Я. Биржевое дело / Г.Я. Резго, И.А. Кетова. - М.: Финансы и статистика: ИНФРА-М, 2009. - 288 с.

26.Рынок ценных бумаг / под ред. Е.Ф. Жукова. - М.: ЮНИТИ-ДАНА, 2009. $-568 \mathrm{c}$.

27.Рынок ценных бумаг: учебник / под ред. В.А. Галанова, А.И. Басова. М.: Финансы и статистика, 2006. - 448 с.

28.Сребник, Б.В. Рынок ценных бумаг: учеб. пособие / Б.В. Сребник. - М.: КНОРУС, 2010. - $288 \mathrm{c}$.

29.Твардовский, В. Теория и практика торговли на фондовом рынке / В. Твардовский. - М.: SmartBookЭкзамен, 2011. - 296 с.

30.Фельдман, А.Б. Производные финансовые и товарные инструменты: учебник / А.Б. Фельдман. - М.: Финансы и статистика, 2003.

31.Ценные бумаги: учебник / под ред. В.И. Колесникова, В.С. Торкановского. - М.: Финансы и статистика, 2002. - 448 с.

32.Чернецкая, Г.Ф. Рынок ценных бумаг и биржевое дело: практикум / Г.Ф. Чернецкая. - М.: Инфра-М, 2001. - 152 с.

33.Янукян, М.Г. Практикум по рынку ценных бумаг / М.Г. Янукян. СПб.: Питер, 2006. - 192 с. 